\title{
Tannins extraction: a key point for their valorization and cleaner production
}

Pedro L. de Hoyos-Martínez ${ }^{1,2}$, Juliette Merle², Jalel Labidi ${ }^{1}$, Fatima Charrier - El Bouhtoury $^{2 *}$

1 Chemical and environmental engineering department, University of the Basque Country, Plaza Europa, 1, 20018, Donostia-San sebastián, Spain.

${ }^{2}$ CNRS/UPPA PAU \& PAYS ADOUR/ E25 UPPA, Institute of Analytical Sciences and Physico-Chemistry for Environment and Materials (IPREM), IUT des Pays de l'Adour, 371 Rue de Ruisseau, 40004 Mont de Marsan, France

\section{*Corresponding author:}

Fatima Charrier - El Bouhtoury: fatima.charrier@univ-pau.fr

\begin{abstract}
:
Tannins are phenolic compounds with considerable abundance in nature. They have attracted significant attention lately owing to their huge variety of potential applications. Accordingly, the tannin-related activity in terms of research has undergone a great boost, especially as green feedstock for materials in several fields. Nevertheless, the extraction process remains as the main bottleneck for their valorization, due to their heterogeneous nature. In the present review, a comprehensive study of the main types of tannins extraction techniques was carried out based on the works from the last 20 years. The literature review was carried through analysis of an initial sample of works followed by snowballing process, obtaining the main extraction parameters of each method. Thereby, the different tannins extraction methods were assessed and their major strengths and weaknesses elucidated. Moreover, a direct comparison between the different techniques was done, leading to the main prospectives for the efficient and clean tannins extraction and production.
\end{abstract}

Keywords: tannin, polyphenols, novel extraction techniques, green production

Abbreviations: GA-gallic acid, HHDP-hexahydroxyphenic acid, EA-ellagic acid, SLESolid-liquid extraction, HWE-hot water extraction, SFE-supercritical fluid extraction, PWE-pressurized water extraction, MAE-microwave assisted extraction, UAEultrasound assisted extraction.

\section{Highlights:}

- The great potential of tannins is hindered by their extraction process

- A literature review was carried out assessing the main tannins extraction methods

- Novel extraction techniques represented a greener option for tannins production

- $\quad$ Combination of novel techniques is an interesting option for industrial scale up 


\section{INTRODUCTION}

Tannins are the most abundant components extracted from biomass, after cellulose, hemicelluloses and lignin (Arbenz and Avérous, 2016). Besides, they represent the second most extensive source of phenolic compounds after lignins (Laurichesse and Avérous, 2014).

Among the vegetal kingdom, tannins are extensively well distributed in both terrestrial and aquatic environments (Barbehenn and Peter Constabel, 2011). Terrestrial tannins, can be found in tropical, arid and semi-arid areas but also in other regions, like Atlantic or Mediterranean ones (Balogun et al., 1998; Jackson et al., 1996). They are present in high concentrations in several species such as Schinopsis balansae (quebracho wood), Acacia mearnsii (black mimosa bark), Pinus radiata and Pinus nigra (pine species), Quercus spp (oak bark.) and Castanea sativa (chestnut wood). They are also found in considerable amounts in various seeds (cocoa, guarana, kola, areca) and leaves (hamamelis, green tea) (Bele et al., 2010; Lochab et al., 2014). They are visibly present too in everyday life products like tea or wine (Mattivi et al., 2009). On the other hand, in aquatic environments tannins occur in smaller extent and prominently in non-vascular plants such as algae (Kirke et al., 2017).

Tannins major features are derived from their phenolic nature. For instance, their antioxidant capacity is linked to the phenolic rings present in their structure, which can act as electron scavenger to trap ions and radicals. Owing to this antioxidant nature, tannins are widely utilized in different areas such as the pharmaceutical, medical or food industry (Chen et al., 2016; Ismail et al., 2016; Park et al., 2014). Tannins phenolic character makes them a potential source of products in the chemical industry as well, as substituent in phenolic resins for several applications (Chupin et al., 2015; Jahanshaei et al., 2012; Ramires and Frollini, 2012).

This abundance in nature and variety of applications have encouraged a growing tendency in the tannins-related research in the last 20 years (figure 1).

Accordingly, they are considered an attractive family of compounds in terms of potential applications and environmental friendliness. However, one important aspect of tannins is their heterogeneous nature which makes impossible to settle a universal method for their extraction (Hagerman, 1988). The yield, purity and composition of the extracts rely normally on several parameters such as the vegetal source, technique employed, extraction time, temperature etc. (Bacelo et al., 2016). Thereby the extraction of tannins from vegetable residues is a process, which constitutes a crucial keypoint for their reuse, valorization and their sustainable production (Bacelo et al., 2017).

In the literature there have already been efforts towards the analysis of the phenolic compounds extraction from plants by different methods (Khoddami et al., 2013; Xu et al., 2017). However, plants polyphenols include a vast range of compound such as flavonoids, phenolic acids, tannins, stilbenes and lignans. For this reason, these works usually lack of specificity concerning the results given. This review was focus only on the extraction of tannins and therefore the results 
were provided in terms of specific tannin amounts or tannin equivalents. Moreover, the discussion and evaluation of the different methods presented is exclusively oriented to the tannins cleaner production.

This study aims to describe the evolution of the existing methods for tannin extraction through a comprehensive critical literature review. A detailed comparison between the different techniques was carried out. The main strengths and weaknesses of each methodology are presented, providing a better understanding in the matter and the future lines for the tannins cleaner and more efficient manufacture.

The work structure is divided in several parts. After the introduction, section 2 is presented covering a brief state of the art on the field of tannins related to the tannin extraction. Then section 3 , describes the methodology employed for carrying out this research. Section 4 displays the main results related to tannins extraction by the different methods, an in-depth comparison between them and a full discussion of the major advantages and disadvantages of each one. The study is concluded with the main outcomes and future perspectives.

\section{BACKGROUND}

\subsection{Tannin definition}

The "tannin" definition has its origin in the primary function of this group of compounds i.e. tanning. The tanning process has been important along history since it allowed the protection of animal skins turning them into leather by means of plant extracts. The first species reported for tanning leather was oak, which was actually designated with the name "tann" among the Celts (Arapitsas, 2012; Frutos et al., 2004).

One of the first tannins definitions was given by A. Seguin in 1796, who described them as substances in vegetable extracts used for converting animal skins into stable leather (Bele et al., 2010). Nevertheless, it was not until the early 1960s that a more accurate definition of tannin was introduced by Swain and Bate-Smith in 1962. They defined tannins as "naturally occurring water soluble polyphenolic compounds having a molecular weight between 500 and 3000, capable of precipitating alkaloids as well as gelatin and other proteins from aqueous solutions"(Bate-Smith and Swain, 1962). This definition is the one most frequently found and cited within the literature

\subsection{Tannin classification}

The categorization of tannins based on their structural aspects and chemical characteristics is the most extended, since it offers a proper framework for further study. Traditionally, tannins were divided into two major classes namely condensed and hydrolysable tannins. However, currently two other types are also considered i.e. complex tannins and phlorotannins.

Chemically, condensed tannins are defined as polymeric flavonoids (Hagerman, 2002). However, they can appear as oligomers as well, when they are composed of two to ten monomeric units 
1 (Haslam, 2007). In the form of polymeric flavonoids they have limited to no solubility in water,

2 whereas in oligomeric form they are water soluble (Bennick, 2002). Within the flavonoids group,

3 condensed tannins are considered as flavanols, since they are composed of flavan-3-ol moieties

4 (figure 2) (Dai and Mumper, 2010).

5 The flavan-3-ols units can display different structures depending on the type of $A$ and $B$ rings present. $A$ ring can appear as a phloroglucinol or resorcinol moieties (McGraw, 1989), whereas $B$ ring can be arranged as a catechol or pyrogallol units. These combinations lead to the formation of several monomers of condensed tannins (table 1).

The compounds showed in table 1 are the precursors of various types of condensed tannins. In this sense, the condensed tannins whose structure is exclusively composed of (epi)catechins are designated as procyanidins. These are the most abundant type present in plants (Hümmer and Schreier, 2008). On the other part, those tannins mainly formed by (epi)fisetinidol, (epi)robinetinidol and (epi)gallocatechin units, are labelled as profisetinidin, prorobinetidin and prodelphindin respectively.

Hydrolysable tannins are heteropolymers composed of polyphenolic acids and their derivatives, esterified to a polyol (Frutos et al., 2004). This polyol, generally a carbohydrate, forms a central core to which several polyphenolic acid units are attached via ester bonds (figure 3).

Gallic acid (GA) is the most basic block attached to the core of the monomeric units (Hernes and Hedges, 2004). Gallic acid moieties can yield other derivatives such as hexahydroxydiphenic acid units (HHDP), via oxidative coupling of two or more molecules (Hartzfeld et al., 2002). In turn, the HHDP units can spontaneously lactonize to ellagic acid (EA) moieties upon hydrolysis (Landete, 2011). In figure 4, the transformation between the different polyphenolic acids, which can be present in hydrolysable tannins structure are showed. The distinctive property of hydrolysable tannins is their ability of being fractionated hydrolytically into their basic components. This is due to their ester bonds, which are susceptible to break via hydrolysis under acidic and basic conditions. Thererby, they are usually classified into two main subcategories i.e. gallotanins and ellagitannins.

Gallotannins: they represent the simplest kind of hydrolysable tannins and consist of galloyl or digalloyl units linked to a polyol core and therefore they have the ability to yield gallic acid from the hydrolysis reaction.

Ellagitannins: this kind of tannins are characterized by having one to several HHDP units attached to a polyol core. Upon hydrolysis, ellagitannins are able to produce HHDP free units, which spontaneously turn into the dilactone (ellagic acid).

Another type of tannins out of the traditional tannin classification is complex tannins. This kind is characterized by the present of monomeric units of hydrolysable and condensed tannins (Hatano et al., 1991). They are composed of a gallotannin or ellagitannin moiety and a flavan-3-ol building 
1 block connected through a carbon-carbon linkage. This type represents a minoritary group within

2 the tannins family. A typical example of this kind of compounds is accutisim A (figure 5).

3 The other type of tannins discovered in the recent years is phlorotannins. This group is 4 prominently found in brown algae and is composed of phloroglucinol units $(1,3,5-$ 5 trihydroxybenzene). The research carried out lately on this group of tannins, has led to the

6

7 structural elucidation of more than 150 compounds with a large range of molar masses between 126-625000 g·mol-1 (Glombitza and Pauli, 2003; Lopes et al., 2012; Sathya et al., 2017).

Structurally phlorotannins form dehydro-oligomers and polymers of phloroglucinol moieties linked via aryl-aryl (C-C) and diaryl ether bonds (C-O) (Koivikko et al., 2008).

Considering the previous information, it is clear tannins can display a variety of structures resulting in diverse chemical compositions. This aspect, which discussed in the next point, is of considerable importance, since it can have a direct impact over the extraction efficiency.

\subsection{Tannins abundance and occurrence in nature}

In nature, tannin content depends on several aspects such as the plant part and species considered. Within the same species, the tannin content is reported to vary between the different parts with special abundance in barks, leaves, seeds, roots and rhizomes (Bele et al., 2010). In addition, their content can also vary with seasonal and environmental factors e.g. water availability, temperature, light intensity and soil quality (Frutos et al., 2004). These points have a relevant importance, since they can influence the results of the different extraction methods. In the literature, there are several works assessing the effect of different species and plant parts on the tannin extraction results (Geoffroy et al., 2017; Tabaraki et al., 2013). In this sense, it was reported by Cheng et al. (2012) that the variety of the grape employed significantly influenced the amount of tannins quantified in the extracts (Cheng et al., 2012). They found that the extracts of the variety Pinot Noir presented higher amount of tannins (gallic acid equivalents) than Pinot Meunier. This was attributed to the different viticultural practices and environmental conditions. Moreover, the amount of tannins was higher in the seeds compared to skin and pomace. In another work, tannins from different spices were extracted via microwave and ultrasound and significant differences regarded. Again, the variety of spice was confirmed to have a major role. Thus, the extraction for Crocus sativus resulted in a tannin amount thirty times higher than that of Coriandrum sativum (Gallo et al., 2010). Besides, the spices were reported to provide higher tannin amounts in the extracts by means of microwave assisted extraction than ultrasound.

Regarding tannin chemical composition, species have a direct influence as well. It has been reported that different plants species display diverse physico-chemical properties, derived from the distinct types of tannins present (Mangan, 1988). In the previous section, it was discussed that the different type of tannins can lead to various chemical compositions, based on their structure. Thus depending on the species, diverse types of tannins could be extracted and therefore the tannin composition of the extracts would be different. A research carried out by Bianchi et al. 
1 (2015), proved that the tannin composition of the extracts from different wood barks species

2 extracted under the same conditions showed several divergences (Bianchi et al., 2015). Thereby,

3 a predominant amount of prodefinidins was determined in Silver fir, whereas a higher amount of

4 procyanidins was found for European Larch. They reported too, that the tannins composition of

5 these species substantially differ from those of tropical species such as Mimosa and Quebracho.

6 This divergences were also displayed on another work on tannin extraction from the seeds of

7 different varieties of grapes (Mattivi et al., 2009). The results showed significant variations

8 between the major tannin monomers present in the different grape species.

\section{3. METHODS AND RESEARCH DESIGN}

In this section, the different steps followed for carrying out the bibliographic review are showed, including the search, selection and analysis of articles and limitations.

In the preparation of this review, two bibliographic databases were selected: Scopus and Web of science (all databases). Scopus is reported to cover more than 21500 journals from social, life, health and physical sciences (Elsevier, 2016) whereas Web of science includes over 12000 different journals from science, arts and humanities (Thomson Reuters, 2013). For this reason, these two directories were chosen since they are said to comprise the major part of the articles related to the topic of tannins cleaner production. The selection of the published works was refine by selecting different subjects of interest. A previous search based on the topics of tannin definition, classification and distribution in nature was carried out to provide some background on the field (section 2). Then, the main search linked to the major topic of this work i.e. extraction of tannins was performed. First, general information was seeked about each technique to introduce the main principles of the extraction methods. Afterwards, the results from each method (main extraction parameters) were searched, aiming the comparison between the different techniques and the assessment of their major strengths and weaknesses (section 4).

\subsection{Choice of search terms and selection of articles}

Regarding the major topic, a general bibliographic search was firstly made by using the search string [tannin AND extraction]. This search produced approximately 4500 hits, from which the main methods of tannin extraction and production were obtained. The selection of the different methods was based on the search of keywords in the articles titles and abstracts (e.g. ultrasound assisted extraction, solvent extraction, pressurized water extraction). Then, a narrower search (based on these terms) was done focusing specifically on each extraction technique and giving a considerable smaller number of hits. The parameters employed for this search are presented in table 2. All the hits given in this table, were scanned by their titles, abstracts and keywords. Then the most relevant articles were imported to the Mendeley $(\mathrm{C}$ reference management system. From this sample, the articles were sorted into eight different categories: 
1) Conventional tannins extraction with organic solvents

2) Tannins extraction with hot water

3) Tannins extraction with ionic liquids

4) Tannins extraction with supercritical fluids

5) Tannins extraction with pressurized hot water or subcritical water

6) Tannins extraction assisted by microwave

7) Tannins extraction assisted by ultrasound

8) Comparison of tannins extraction with several extraction methods

The articles that did not belong to any category or that were duplicated in a previous category were removed. To this sample of selected and categorized articles, a semi structured snowballing approach followed (Wohlin and Claes, 2014). Thus, it was possible to add to our sample works that were not found in the previous search and categorization (figure 6).

\subsection{Method of analysis and limitations of research}

The final sample of articles was analysed by thoroughly examine their content (specially the results and discussion section). Thus, bibliometric information about the main extraction parameters was gathered and summarized for each article. These parameters include the plant species extracted, conditions of extraction (temperature, pressure and times), solvents involved, extraction yields and tannin content of the extract. The data collected was analysed to discuss the main results and tendencies and to compare the divergences between the extraction methods.

Regarding the limitations of the review, it was decided to focus mainly on peer-reviewed articles written in English. The period of time selected was comprising the last 20 years of research on the field (between 1997-2018).

\section{RESULTS AND DISCUSSION}

Within this section, the main parameters of the tannin extraction methods are presented and examined. A comprehensive comparison between the different techniques is intended as well.

\subsection{Extraction parameters for each extraction process}

Here the conditions used and the yields obtained for each extraction procedure are presented according to the sample of papers selected from the literature. The aim is the identification of the strengths and weaknesses of each method and the influence of the different parameters over the process.

\subsubsection{Solid-liquid extraction (SLE)}

This section is devoted to the extraction of tannins exclusively based on the contact between a solvent and a solid matter, without any further assisting mechanism. During this kind of extraction, the solvent penetrates into the cell wall of the feedstock containing the tannins. Then, they are dissolved and taken out in the form of extracts (Mailoa et al., 2013). This is the simplest 
and most traditional method employed for tannins extraction. Within this part, several types of solvents are studied namely organic solvents, aqueous solutions, water and ionic liquids.

Concerning the use of organic solvents and their aqueous solutions, the extraction is commonly carried out by means of a soxhlet apparatus whose experimental extraction procedure has been described in several works (Jensen, 2007; Luque de Castro and Priego-Capote, 2010). However, other techniques are also employed and reported in the literature such as infusion or maceration. The extraction with water can be carried out under reflux or through simple maceration in flasks or vessels. At the industrial scale it is generally performed on wood barks by percolation or open diffusion (Ciesla, 1998; Myers, 1998).

The extraction with ionic liquids is an alternative based on the substitution of the traditional solvents with these new liquids, which are known for having unusual combination of properties such as negligible vapour pressure, high thermal stability and dissolution of a broad range of compounds present in plants (Olivier-Bourbigou et al., 2010).

In table 3 is presented a sample of works from the literature devoted to solid-liquid extraction with the previously commented solvents. In regards to these results, it is seen that a considerable percentage of recovery of extracts is achieved by this method. The content of tannins in the extracts is reported to be high as well and can reach even to yields of 96\% (grams of reactive tannins per gram of extract) (Vázquez et al., 2001). However, the results presented are influenced by several parameters. Within these parameters, the nature of the solvent employed for the extraction is regarded to be of significant importance. It is reported that the extraction yields increase with the solvent polarity (Markom et al., 2007). Accordingly, high extraction yields are generally obtained using water or methanol as solvent whereas poor extraction efficiencies are achieved with hexane (Widyawati et al., 2014). The employment of water is normally preferred, especially at the industrial scale owing to environmental reasons. Nevertheless, the solution of tannins in water generally leads to acidic pHs (Vieira et al., 2011). Under these conditions, the formation of insoluble precipitates due to tannin self-condensation reactions is promoted, limiting the extraction efficiency (Sealy-Fisher and Pizzi, 1992). The addition of certain amounts of $\mathrm{NaOH} \%$ is proposed as an alternative to overcome this problem, since it is capable of improving the extraction yields (Chupin et al., 2013). Similarly, the use of salts like sodium carbonate $\left(\mathrm{Na}_{2} \mathrm{CO}_{3}\right)$ and sodium bisulfite $\left(\mathrm{NaHSO}_{3}\right)$ is able to increment the extraction efficiency and to lower the high viscosity of the extracts derived from the tannin self-condensation reactions (Panamgama, 2007). In both cases, the increment of extraction yields is related to the alteration of the $\mathrm{pH}$. Alkaline $\mathrm{pH}$ values are reported to increase the percentage of extracts, owing to the partial break of pyran rings in phlobaphenes (tannin-derived compounds). It has been presented in a recent work, that even the change of $\mathrm{pH}$ from neutral to slightly alkaline values can lead to higher extraction yields (Lochab et al., 2014). Moreover, a relationship between the base concentrations and the extraction yields is observed. The use of higher percentages of these 
components is proved to reach higher extraction yields compared to lower concentrations (AntwiBoasiako and Animapauh, 2012; Inoue et al., 1998). Nevertheless, the increment of the concentrations can provide a lower tannin content in the extracts due to the raise of undesirable non-tannin components (Ping et al., 2011). For this reason, the indiscriminate increase of the alkaline compounds and salts concentrations is not desirable. Different works were found underlining the importance of employing moderate amount of these compounds (Aires et al., 2016; Vieira et al., 2011).

Regarding the tannin content in the extracts, methanol and ethanol provide the best results (do Prado et al., 2014; Widyawati et al., 2014). For instance, it is stated in a work about anthocyanidins extraction from Phyllantus niruri, that methanol and ethanol are more suitable for performing the extraction compared to water (Kaur and Kaur, 2016). This is due to the fact that these organic solvents have more similar characteristics to anthocyanidins.

The use of aqueous solutions of organic solvents has proved its efficiency as well, providing both considerable extraction yields and levels of tannins in the extracts (Vijayalaxmi et al., 2015; Widyawati et al., 2014). Besides, they present the advantage of being able to regulate the polarity of the solvent by adjusting the ratio of both components.

Compared to already mentioned solvents, ionic liquids represent a novel type still under development for tannins extraction. Despite this fact, they have already proved to achieve comparable or even better results than water (Chowdhury et al., 2010). Among this type of solvents, the imidazolium-based ionic liquids are said to be preferred and their concentrations have a direct influence on the results. It is reported that the increase of this parameter provides higher tannins extracted until certain point where not further improvement is regarded (Z. Liu et al., 2016; Lu et al., 2012). For this reason, the concentration of the ionic liquid is normally optimized. Another relevant factor in the tannins extraction with these solvents, is the alkyl chain length of the cation linked to the ionic liquid. It is presented that the increase of the alkyl chain length decrease the surface tension and increment the hydrophobic nature and viscosity (Ćurko et al., 2017). Thus, the ionic liquid can have a stronger interaction with the tannins extracting higher amounts. Above butyl chains, this effect is reported to be the opposite. Consequently, the alkyl chain length of the cations is also further optimized within the different studies.

Apart from the solvents nature, other parameters are regarded to have a major influence over the results namely temperature of extraction, time of extraction and solid to liquid ratio.

Concerning the time of extraction, it is seen that the increment of this parameter provides a higher content of tannins extracted as presented in some of the works from literature (Baldosano et al., 2015; Chowdhury et al., 2010). This is due to the longer times the solute and the solvent are in contact, which favours the mass transfer between both components. Nevertheless, the increase of the extraction times beyond certain values is not desirable. It was discussed by Tan et al. (2013) that the amount of tannins extracted above $4.5 \mathrm{~h}$ was dramatically decreasing towards a minimum 
1 (Tan et al., 2013). This was explained by the fact that an equilibrium was reached between the

2 tannins concentration in the plant matrix and the solvent (Fick's law of diffusion), resulting in the slowdown of the extraction. Besides, at longer times the possibility of tannins degradation owing to the extraction conditions is enhanced.

5 The temperature of extraction is observed to increase the extraction yields as displayed in the results from table 3 (Kemppainen et al., 2014; Vázquez et al., 2001). This enhancement is due to the increase of the mass transfer coefficient at higher temperatures (Huang et al., 2016). Moreover the increment of the temperature results in the improvement of the solute solubility and diffusion coefficient and also decreases of solvent viscosity, which promotes the extraction (Al-Farsi and Lee, 2008). This parameter is normally regulated and optimized, since high temperatures can also lead to lower amount of tannins in the extracts as showed by Ramos et al. (2013) (Ramos et al., 2013). This was attributed to the denaturation of these compounds owing to the harsh conditions employed. The use of too high temperatures can also result in solvent evaporation. For this reason, in this kind of extraction the temperature is normally set up at the solvent boiling point. Regarding ratio solid-liquid, it is showed that the decrease of this parameter provides higher extraction yields, since higher amounts of solvent are employed (Politi et al., 2011). Nevertheless, at low solid-liquid ratios, the differences between the extraction efficiencies are normally minimized and therefore this parameter is generally optimized at certain value.

To conclude, it can be remarked that the main general advantages of this method are its simplicity, efficiency and low cost. In the case of the extraction with hot water, it should be highlighted as well the fact that it can be successfully transferred to the industry, especially the extraction from wood barks (Amaral-Labat et al., 2013; Kemppainen et al., 2014). On the other hand, the major drawbacks of this method are the long times needed for the extraction, which can range from several hours to even several days, and the great amount of solvent normally employed. These disadvantages could be minimized by the use of ionic liquids, which display special properties favorable to the extraction (Hernández-Fernández et al., 2015). Nevertheless, the high prices of this novel solvents and the difficulty to recover the solute from the ionic liquid are still hindering their utilization.

\subsubsection{Supercritical fluid extraction (SFE)}

In this part, the extraction of tannins by using supercritical fluids is presented. The principle of this method is based on the concept of critical point, which is defined as the highest temperature and pressure at which a pure substance can exist in a vapour-liquid equilibrium (Ajila et al., 2011). Above this point a fluid shares properties between a gas and a liquid, such as the typical weight of liquids with the penetration power of gases (Azmir et al., 2013). The works found in the literature related to this technique are presented in table 4. In regards to the presented results, various common characteristics are identified. The most widely employed solvent among all the works is carbon dioxide $\left(\mathrm{CO}_{2}\right)$. This is due to its desirable properties such as non toxicity, non- 
1 flammability, non-corrosive nature, availability and low critical temperature and pressure $\left(31^{\circ} \mathrm{C}\right.$

2 and 7.28 MPa) (Palmer and Ting, 1995; Talmaciu et al., 2016). The range of pressures and temperatures used within the different works for this fluid is between 10-65.5MPa for the former parameter and between $40-88^{\circ} \mathrm{C}$ for the later.

5 Concerning the extraction yields and tannins extracted, the parameter with the greatest influence 6 is the utilization of a co-solvent. Thus, poor extraction yields are achieved using supercritical $\mathrm{CO}_{2}$ 7 alone whereas considerable enhancements are reported after the addition of a co-solvent 8 (Cavalcanti et al., 2012; Conde et al., 2013). This is due to the non-polar nature of $\mathrm{CO}_{2}$ as solvent and the polar nature of most of tannin compounds. The addition of co-solvents of polar nature such as ethanol, methanol or aqueous mixtures help ameliorating the solvating power of $\mathrm{CO}_{2}$ towards tannins and improves the extraction yields. The pressure employed also presents a major role in the extraction efficiency and amount of tannins extracted. It is observed that the increment of the pressure promotes the extraction of tannins (do Prado et al., 2014). The reason for that is that at higher pressures the fluid density is increased, decreasing the distance between the molecules and therefore improving the interactions fluid-matrix (Maran et al., 2015).

Regarding the temperature of extraction, low values are said to be preferred. This parameter do not show though a crucial influence over the process, since most of the works do not report big differences in terms of extraction yields and amount of tannins extracted. However, it has been presented that higher temperatures can lead to lower amounts of tannins in the extracts (Luengthanaphol et al., 2004).

The main advantages concerning this extraction method are the utilization of mild temperatures and a nontoxic solvent $\left(\mathrm{CO}_{2}\right)$ which can be easily removed and can avoid further oxidation reactions by creating an oxygen free environment. On the other side, one of the main drawbacks are the high investment costs, due to the high pressures needed for the extraction process (Perrut $\dagger$, 2000). The other main problem concerning $\mathrm{CO}_{2}$ is its non polar nature, which reduces the extraction power towards tannins (low solubility of polar compounds). Consequently, the addition of co-solvents such as methanol, ethanol, acetone or water, becomes an essential requirement

\subsubsection{Pressurized water extraction (PWE)}

This extraction method is based on the use of water as solvent at high pressures and temperatures, generally at subcritical conditions i.e. between its atmospheric boiling point $\left(100^{\circ} \mathrm{C}, 0.1 \mathrm{MPa}\right)$ and its critical point $\left(374^{\circ} \mathrm{C}, 22.1 \mathrm{MPa}\right)$. Within this range water is maintained in the liquid state but properties such as the polarity, viscosity, surface tension and disassociation constant are considerably lowered compared to water at ambient conditions (Liang and Fan, 2013). The reduction of these parameters enhances the mass transfer of the tannins from the feedstock matrix (Vergara-Salinas et al., 2013). Besides, under these conditions the ability to extract different types of compounds from this family is improved (Rangsriwong et al., 2009). The main difference with traditional solid-liquid extraction using hot water, is that pressurized water extraction utilizes 
temperatures above the boiling point and pressures above the atmospheric to maintain water in liquid state.

The results related to this extraction method are presented in table 5. It is observed in most of the works, that the extraction was carried out at subcritical conditions $\left(0.1-22 \mathrm{MPa}, 100-374^{\circ} \mathrm{C}\right)$.

Nevertheless, in some works pressures above the critical point are reported as well, to improve the results. A significant characteristic of this method is the reduction of the extraction times needed (5-60 minutes). Despite the short extraction times, high extraction yields are reported even up to $\approx 70 \%$ (Erşan et al., 2018). Furthermore, by adjusting the pressure and temperature of the solvent, its polarity can be modulated and a wide variety of tannins in significant amounts can be extracted depending on the source. For this reason, both variables present a significant influence in the extraction process.

The temperature plays a major role and its increment leads to higher extraction yields (Sousa et al., 2016). This effect is attributed to the fact that at higher temperatures the solvent is more easily diffused into the plant matrix. Moreover at higher temperatures the solute vapour pressure is incremented and it is easier for the solute to free itself from the matrix (Markom et al., 2010a). However, the employment of too severe temperatures was proved to have a negative effect, particularly on the tannin content of the extracts (García-Marino et al., 2006; Rangsriwong et al., 2009). This is associated to the possible degradation and denaturation of the different polyphenolic compounds at harsh temperatures (Vergara-Salinas et al., 2013).

Concerning the pressure, the influence on the water properties is little as far as it stays as a liquid (Plaza and Turner, 2015). For this reason, its effect on the results of extraction is normally lower. Despite this fact, the increase of this parameter can result in slightly higher extraction yields and tannin content in the extracts until certain pressure values (Aliakbariana et al., 2012). Above these pressure values the solvent solubility is not further improve and accordingly the extraction yields remain or even slightly decrease as well as the amount of tannin extracted (Markom et al., 2010a). The main advantages of this method are the reduced handling time and solvent consumption and the no utilisation of toxic organic solvents. Another advantage is the possibility to extract selectively tannins of different polarities by the modification of the temperature, pressure or cosolvent. On the other hand, the major disadvantages are related to the high temperatures and pressures used (reduction of the extraction selectivity and possible degradation of the analytes) and the expensive equipment required (solvent transporting pump, a pressure vessel and system controller, and a collection device for the extract needed).

\subsubsection{Microwave assisted extraction (MAE)}

This method is based on the combination of the traditional solvents employed for tannins extraction and the fast heating in the microwave field. In some cases, the extraction process is ameliorated because both the solvent and the sample can be rapidly heated by direct interaction with electromagnetic radiation (depending on their dielectric characteristics). Another possibility 
1 is the heating of one of the components by interaction with the other, previously heated by the

2 microwave irradiation. The effect of heating on the solvent increases its solubility, whereas on

3 the material it improves porosity allowing an easier penetration of the solvent (Routray and Orsat,

4 2012). Thereby, in either case the extraction of tannins from the cell wall of the feedstock is eased.

5 Within this section, a sample of papers focused on the tannins extraction assisted by microwave

6 is displayed (table 6). From the previous results, it is remarked the short times needed for

7 extraction (1-20 minutes), which achieved a significant level of tannin extraction. Regarding the solvent employed, the volume used for the extraction has a direct impact on the amount of tannins extracted. Normally a larger amount of solvent is supposed to achieve a higher quantity of tannins extracted, according to the principle of equilibrium between solvents and materials. In a work by Wang et al., 2010 (Wang et al., 2010), it was found that the increase of the solvent volume led to the enhancement of the tannins extracted until certain point (ratio 1:30) and then decreased. This was attributed to the relatively large amount of solvent employed, which resulted in a dilution of the amount of the tannins in the extracts (Guo et al., 2001; Xiao et al., 2008). The nature of the solvent also plays a major role on the extraction as was already mentioned in section 4.1.1 Accordingly, the increase of the polarity of the solvent leads to higher amounts of tannins extracted (Pan et al., 2010). The effect of the microwave power was discussed in several works as well (Naima et al., 2015; Švarc-Gajić et al., 2013). It is proved that the increase of the power leads to higher amounts of tannins extracted. This is due to the enhancement of the solvent penetration into the matrix and the faster energy transfer to the solvent and material. However, above high values of microwave irradiation, the amount of tannins extracted is observed to decrease. Normally, this fact is due to the thermal degradation of the tannins, which results in a lower content of these compounds in the extracts (Dahmoune et al., 2015). It has been showed as well that too high microwave power can provide excess of energy to the solvent and material. This superfluous energy can generate abnormal molecular interaction, which affect the extraction yields of tannins (Jin et al., 2010). Consequently, this parameter is normally optimized in the majority of the works to achieve the highest amount of tannins recovered.

The main advantages of this method are the employment of considerably short extraction times, and lower amount of solvents compared to traditional solid-liquid extraction. Another advantage is the agitation provided by the microwave irradiation, which can ameliorate the mass transfer phenomenon (Jain et al., 2013). The main disadvantages are the great costs of the equipment needed (specially at larger scale) and the possibility of thermal degradation of the feedstocks and tannins, especially those with high number of hydroxyl groups (Xu et al., 2017).

\subsubsection{Ultrasound assisted extraction (UAE)}

The extraction of tannins by this technique is based on the formation, growth and collapse of micro bubbles inside a liquid phase submitted to ultrasonic cavitation (Chemat et al., 2011). The bubbles are induced by sound waves, with frequencies above $20 \mathrm{kHz}$, which cause mechanical 
1 vibrations into the plant matrix. These mechanical vibrations, can rupture cell wall tissues

2 ameliorating the penetration of the solvent into the matrix and achieving higher amounts of

3 tannins extracted (Ali et al., 2018).

4 In this section, a sample of works related to the extraction of tannins assisted by ultrasound, is

5 discussed (table 7). Within the works presented, the influence of several parameters on tannin extraction efficiency is observed. Again, the solvent employed has a prominent effect and therefore the use of more polar solvents leads to the improvement of the extraction yields. Nonetheless, it was reported that ethanol and methanol presented a higher selectivity to the polyphenolic compounds, providing higher amounts of tannins in the extracts (Dhanani et al., 2013; Tabaraki et al., 2013). Regarding the extraction times, not high values are needed to achieve good extraction yields (below 1hour). The increment of this parameter can lead to higher extraction yields and amount of tannin in the extract (Ivanovic et al., 2014). However, when the extraction time is incremented above relatively high values, the extraction efficiency tends to decrease. A first work by Dalzell and Kerven, (1998) showed that sonication after 30 minutes decreased the tannins extraction efficiency from Leucaena spp. This result was attributed to the possible degradation of the proanthocyanidins due to the increased temperature of the water bath, provided by the prolonged sonication time (Dalzell and Kerven, 1998). In another work, the decrease of the tannins extracted at high extraction times was associated to the prolonged interval of sonication and the possible degradation of the tannins as well but also to the lower concentration gradient of the solvent (Annegowda et al., 2012). A similar tendency is observed for the sonication power. Hence, the increase of this parameter provides higher amounts of tannins extracted until certain point and then began to decrease (Agarwal et al., 2018; Chavan and Singhal, 2013). This is due to the chemical decomposition of tannins extracted. Taking the previous phenomena into consideration, a further optimization of the conditions was carried out in most of the works presented. The major advantages of this technique are the short extraction times employed and the fact that it is a simple and inexpensive extraction method (Khoddami et al., 2013). On the contrary, the main drawbacks are the lack of uniformity in the intensity of ultrasounds (maximum peak observed in the vicinity of radiating surface and decreasing with the distance to the source) and the reduction of the power with the time (Routray and Orsat, 2012).

\subsection{Comparison of extraction methods}

In this section, a sample of works devoted to the analysis and assessment of various extraction methods for tannins extraction is presented. A comprehensive and direct comparison between the different techniques is provided as well (table 8). In the majority of the studies, the most traditional tannin extraction method namely solid-liquid extraction, was contrasted with other modern techniques. 
1 Considerable differences are regarded between SLE and SFE, especially when no co-solvent was

2 used (Reátegui et al., 2014). SLE can achieve a higher amount of tannins extracted owing to the more polar nature of the solvent and the longer times employed. It is regarded though, that the addition of a more polar co-solvent or the use of simultaneous sonication highly ameliorates the results of SFE. Thereby, the amounts of tannins extracted are comparable to those of SLE but employing lower times. Concerning PWE, it is reported that the amount of tannins extracted compared to that of traditional method SLE is enhanced owing to the increased solvating power of water under subcritical conditions (Rangsriwong et al., 2009). Moreover, the extraction times are considerably lowered.

Other recent techniques such as MAE and UAE have been also compared to SLE within the literature (Aspé and Fernández, 2011; Belwal et al., 2017; Ghadage et al., 2017). Superior performance is displayed by MAE and UAE in terms of higher extraction yields and amount of tannins recovered. This is due to the acting mechanisms of both methods, which ameliorates the penetration power of the solvent and extraction efficiency of the tannins from the plant matrix. Furthermore, the extraction times can be dramatically decreased by more than a $95 \%$ in some of the cases and the amount of solvent used lowered. The use of ionic liquids also provides a great improvement in the extraction of tannins compared to the performance of conventional organic solvents in SLE (Ribeiro et al., 2013)

Within the presented results, a comparison between the modern tannin extraction techniques is observed as well. For example, it was presented that the SFE was able to obtained similar extraction yields to that of UAE. Nevertheless, it was reported to recovered substantially lower amounts of tannins (Pereira et al., 2017, 2016).

In regards to the results presented in table 8, MAE, UAE and PWE are the techniques with the best future perspectives for tannin extraction. Some works were found providing a further comparison between them and the conventional extraction methods (Veličković et al., 2017). In terms of extraction yields, PWE was able to achieve the highest values, followed by MAE and UAE. Nonetheless, concerning the amount of tannins extracted no considerable differences were observed. The main advantage of PWE compared to MAE and UAE, was the use water as solvent instead of organic compounds. MAE was able to provide the shortest extraction times (as seen in several works) compared to UAE and PWE (1-5 min for MAE in contrast to 15-30 min for UAE and PWE). Additionally, MAE and UAE can generally perform the extraction at lower pressure compared to PWE, which requires the use of subcritical conditions.

The combination of several of these modern techniques is also reported to provide synergistic effects and improved results (Lu et al., 2012). For example, the utilization of simultaneous microwave and ultrasound assisted extraction (UMAE) is proved to provide better results than these methods alone. Moreover, the substitution of the conventional organic solvents by ionic 
1 liquid, shows highly ameliorated results and leads to a promising environmentally friendly option

2 for tannins extraction.

\section{$3 \quad$ 4.2.1 Technical and costs comparison}

4 The major economic and operational considerations in the different extraction methods are 5 generally derived from the amount and nature of solvent employed, the extraction conditions, the recovery of the tannin extracts from the solvent and the equipment required for the process. Regarding these costs and technical characteristics, several differences can be observed.

The industrial production of tannins at the moment, is generally performed using traditional solidliquid extraction. In this regard, water as solvent is preferred in contrast to the organic solvents, owing to the lower emissions of VOC and costs (Lochab et al., 2014). However, there is current a tendency towards the switch of traditional tannin extraction methods by other more environmentally friendly. This is due to the long extraction times and the high amount of solvent required, which has to be evaporated afterwards, resulting in elevated energy costs (Selvamuthukumaran and Shi, 2017).

Consequently, in the majority of the works presented in this study it is showed that the modern extraction techniques are more favourable for future implementation in the industry.

The implementation in larger scale of PWE for tannin extraction was assessed based on a study of the main economic factors by Veggi et al. (2011) (Veggi et al., 2011). Here, it was found that although the addition of a co-solvent can lead to an increment of the manufacturing costs (distillation step for the solvent), in the end the global manufacturing costs were lower owing to the improvement in the recovery of tannins. In addition to that, they reported for the process (design to run $7920 \mathrm{~h} /$ year) manufacturing costs of $983 \$ / \mathrm{Kg}$ for the global yields. In contrast to that technique, Ravber et al (2015) carried out another research with a preliminary economic evaluation of the PWE for tannins extraction from larch wood (Ravber et al., 2015). After optimization of the process $\left(\mathrm{V}_{\text {extrator }}=350 \mathrm{~L}\right.$ and $\mathrm{T}=300^{\circ} \mathrm{C}$, process run $8016 \mathrm{~h} /$ year $)$, they presented operating costs of $223 \$ / \mathrm{Kg}$, achieving an extraction yield of $21.60 \%$. This can provide a more environmentally friendly and cheaper option compared to conventional solid-liquid extraction.

Regarding MAE, moderate global capital costs and good performance at atmospheric conditions are reported as well as lower energy demands compared to traditional extraction method (Bouaoudia-Madi et al., 2017). In addition to that, MAE can be highly improved by the use of ionic liquids as solvent. Liu et al. (2016) pointed out the considerable lower energy requirements compared to conventional SLE (0.13 kWh MAE in contrast to 1.54kWh SLE) (Z. Liu et al., 2016). The employment of MAE has been also promoted in other the works from the literature. For instance, Belwal et al. (2017) presented the need of scaling up the MAE process from the laboratory scale to the industry to harness the potential of tannins (Belwal et al., 2017). In comparison to MAE, UAE has been presented as an alternative as well. In fact, Diouf et al. (2009) found that the energy requirements for UAE were slightly lower than MAE for the same amount 
1 of material extracted $(0.94 \mathrm{kWh}$ and $1.51 \mathrm{kWh}$ respectively) (Diouf et al., 2009). The UAE is also

2 reported to save time, energy and costs compared to conventional SLE. Nevertheless, parameters

3 should be optimized as excessive sonication can increase energy and operational costs (Agarwal

4 et al., 2018).

\section{5. Conclusions}

6 After performing the literature review it was clear the interest on the topic of tannins extraction,

7 taking into account the significant number of works found. Besides, a clear evolution was

8 observed from the traditional extraction method towards the most novel methodologies. The

9 modern tannin extraction methods show a similar or even better performance compared to the most traditional one, in terms of extraction yields and amount of tannins extracted. They also display several advantages concerning the environmental impact such as the reduction of the extraction times and amount of solvent needed, leading to a lower energy consumption. Despite these facts, the truth is that the current industrial tannin production still remains old-fashioned, since it is majorly carried out by solid-liquid extraction using large amounts of water. It has been clearly stated from the works presented here, that lately several efforts are being made towards modern ways of extract tannins. Nevertheless, they usually remain in the laboratory scale. For this reason, an inflection point has to be reached in the short-term to switch from this oldfashioned industrial tannin production system to a state-of-the-art one. With this aim, works should be carried in the following years specially focus on the scale up and the economic analysis of the process of tannins extraction.

Finally, it should be added as well that this change in the tannins extraction methods, not only can lead to a cleaner and more effective production but also can promote and spread tannins utilization in several fields of the industry. This is of major importance since they represent a renewable feedstock with numerous applications. 


\section{REFERENCES:}

Agarwal, C., Máthé, K., Hofmann, T., Csóka, L., 2018. Ultrasound-Assisted Extraction of Cannabinoids from Cannabis Sativa L. Optimized by Response Surface Methodology. J. Food Sci. 83, 700-710. https://doi.org/10.1111/1750-3841.14075

Aires, A., Carvalho, R., Saavedra, M.J., 2016. Valorization of solid wastes from chestnut industry processing: Extraction and optimization of polyphenols, tannins and ellagitannins and its potential for adhesives, cosmetic and pharmaceutical industry. Waste Manag. 48, 457-464. https://doi.org/10.1016/J.WASMAN.2015.11.019

Ajila, C.M., Brar, S.K., Verma, M., Tyagi, R.D., Godbout, S., Valéro, J.R., 2011. Extraction and Analysis of Polyphenols: Recent trends. Crit. Rev. Biotechnol. 31, 227-249. https://doi.org/10.3109/07388551.2010.513677

Al-Farsi, M.A., Lee, C.Y., 2008. Optimization of phenolics and dietary fibre extraction from date seeds. Food Chem. 108, 977-985. https://doi.org/10.1016/J.FOODCHEM.2007.12.009

Alexandre, E.M.C., Araújo, P., Duarte, M.F., de Freitas, V., Pintado, M., Saraiva, J.A., 2017. High-pressure assisted extraction of bioactive compounds from industrial fermented fig by-product. J. Food Sci. Technol. 54, 2519-2531. https://doi.org/10.1007/s13197-017-2697-2

Ali, A., Lim, X.Y., Chong, C.H., Mah, S.H., Chua, B.L., 2018. Optimization of ultrasound-assisted extraction of natural antioxidants from Piper betle using response surface methodology. LWT 89, 681-688. https://doi.org/10.1016/J.LWT.2017.11.033

Aliakbariana, B., Fathib, A., Peregoa, P., Dehghanib, F., 2012. Extraction of antioxidants from winery wastes using subcritical water. J. Supercrit. Fluids 65, 18-24. https://doi.org/10.1016/J.SUPFLU.2012.02.022

Amaral-Labat, G., Grishechko, L.I., Fierro, V., Kuznetsov, B.N., Pizzi, A., Celzard, A., 2013. Tannin-based xerogels with distinctive porous structures. Biomass and Bioenergy 56, 437-445. https://doi.org/10.1016/J.BIOMBIOE.2013.06.001

Annegowda, H. V, Bhat, R., Min-Tze, L., Karim, A.A., Mansor, S.M., 2012. Influence of sonication treatments and extraction solvents on the phenolics and antioxidants in star fruits. J. Food Sci. Technol. 49, 510-4. https://doi.org/10.1007/s13197-011-0435-8

Antwi-Boasiako, C., Animapauh, S.O., 2012. Tannin extraction from the barks of three tropical hardwoods for the production of adhesives. J. Appl. Sci. Res. 8, 2959-2965.

Arapitsas, P., 2012. Hydrolyzable tannin analysis in food. Food Chem. 135, 1708-1717. https://doi.org/10.1016/J.FOODCHEM.2012.05.096

Arbenz, A., Avérous, L., 2016. Tannins: A Resource to Elaborate Aromatic and Biobased Polymers, in: Biodegradable and Biobased Polymers for Environmental and Biomedical Applications. John Wiley \& Sons, Inc., Hoboken, NJ, USA, pp. 97-148. https://doi.org/10.1002/9781119117360.ch4

Ashraf-Khorassani, M., Taylor, L.T., 2004. Sequential Fractionation of Grape Seeds into Oils, Polyphenols, 
and Procyanidins via a Single System Employing CO2-Based Fluids. J. Agric. Food Chem. 52, 24402444. https://doi.org/10.1021/JF030510N

Aspé, E., Fernández, K., 2011. The effect of different extraction techniques on extraction yield, total phenolic, and anti-radical capacity of extracts from Pinus radiata Bark. Ind. Crops Prod. 34, 838-844. https://doi.org/10.1016/J.INDCROP.2011.02.002

Azmir, J., Zaidul, I.S.M., Rahman, M.M., Sharif, K.M., Mohamed, A., Sahena, F., Jahurul, M.H.A., Ghafoor, K., Norulaini, N.A.N., Omar, A.K.M., 2013. Techniques for extraction of bioactive compounds from plant materials: A review. J. Food Eng. 117, 426-436. https://doi.org/10.1016/J.JFOODENG.2013.01.014

Bacelo, H.A.M., Botelho, C.M.S., Santos, S.C.R., 2017. Production of tannin-based adsorbents and their use for arsenic uptake from water, in: Vilarinho, C., Castro, F., Lopes, M. de L. (Eds.), WASTES Solutions, Treatments and Opportunities II:Selected Papers from the 4th Edition of the International Conference on Wastes: Solutions, Treatments and Opportunities. CRC Press (Taylor \& Francis), London, pp. 113-118.

Bacelo, H.A.M., Santos, S.C.R., Botelho, C.M.S., 2016. Tannin-based biosorbents for environmental applications - A review. Chem. Eng. J. 303, 575-587. https://doi.org/10.1016/J.CEJ.2016.06.044

Baldosano, H.Y., Beatriz, M., Castillo, M.G., Danica, C., Elloran, H., Bacani, F.T., 2015. Effect of Particle Size, Solvent and Extraction Time on Tannin Extract from Spondias purpurea Bark Through Soxhlet Extraction. Proc. DLSU Res. Congr. 3, 1-6.

Balogun, R.., Jones, R.., Holmes, J.H.., 1998. Digestibility of some tropical browse species varying in tannin content. Anim. Feed Sci. Technol. 76, 77-88. https://doi.org/10.1016/S0377-8401(98)002107

Barbehenn, R. V., Peter Constabel, C., 2011. Tannins in plant--herbivore interactions. Phytochemistry 72, 1551-1565. https://doi.org/10.1016/J.PHYTOCHEM.2011.01.040

Bate-Smith, E.C., Swain, T., 1962. Flavonoid compound, in: Mason, H.S., Florkin, A.M. (Eds.), Comparative Biochemistry. Academic Press, New York, pp. 755-809.

Bele, A.A., Jadhav, V.M., Kadam, V.J., 2010. Potential of Tannnins: A Review. Asian J. Plant Sci. 9, 209214. https://doi.org/10.3923/ajps.2010.209.214

Belwal, T., Giri, L., Bhatt, I.D., Rawal, R.S., Pande, V., 2017. An improved method for extraction of nutraceutically important polyphenolics from Berberis jaeschkeana C.K. Schneid. fruits. Food Chem. 230, 657-666. https://doi.org/10.1016/J.FOODCHEM.2017.03.086

Bennick, A., 2002. Interaction of plant polyphenols with salivary proteins. Crit. Rev. Oral Biol. Med. 13, 184-96.

Berardini, N., Carle, R., Schieber, A., 2004. Characterization of gallotannins and benzophenone derivatives from mango (Mangifera indica L. cv. "Tommy Atkins") peels, pulp and kernels by high-performance liquid chromatography/electrospray ionization mass spectrometry. Rapid Commun. Mass Spectrom. 
18, 2208-2216. https://doi.org/10.1002/rcm.1611

Bianchi, S., Kroslakova, I., Janzon, R., Mayer, I., Saake, B., Pichelin, F., 2015. Characterization of condensed tannins and carbohydrates in hot water bark extracts of European softwood species. Phytochemistry 120, 53-61. https://doi.org/10.1016/J.PHYTOCHEM.2015.10.006

Bouaoudia-Madi, N., Boulekbache-Makhlouf, L., Kadri, N., Dahmoune, F., Remini, H., Dairi, S., Oukhmanou-Bensidhoum, S., Madani, K., 2017. Phytochemical analysis of Myrtus communis plant: Conventional versus microwave assisted-extraction procedures. J. Complement. Integr. Med. 14. https://doi.org/10.1515/jcim-2016-0098

Çam, M., Hış1l, Y., 2010. Pressurised water extraction of polyphenols from pomegranate peels. Food Chem. 123, 878-885. https://doi.org/10.1016/J.FOODCHEM.2010.05.011

Carrera, C., Ruiz-Rodríguez, A., Palma, M., Barroso, C.G., 2012. Ultrasound assisted extraction of phenolic compounds from grapes. Anal. Chim. Acta 732, 100-104. https://doi.org/10.1016/J.ACA.2011.11.032

Cavalcanti, R.N., Navarro-Díaz, H.J., Santos, D.T., Rostagno, M.A., Meireles, M.A.A., 2012. Supercritical Carbon Dioxide Extraction of Polyphenols from Pomegranate (Punica granatum L.) Leaves: Chemical Composition, Economic Evaluation and Chemometric Approach. J. Food Res. 1, 282. https://doi.org/10.5539/jfr.v1n3p282

Chavan, Y., Singhal, R.S., 2013. Ultrasound-assisted extraction (UAE) of bioactives from arecanut (Areca catechu L.) and optimization study using response surface methodology. Innov. Food Sci. Emerg. Technol. 17, 106-113. https://doi.org/10.1016/J.IFSET.2012.10.001

Chemat, F., Zill-e-Huma, Khan, M.K., 2011. Applications of ultrasound in food technology: Processing, preservation and extraction. Ultrason. Sonochem. 18, 813-835. https://doi.org/10.1016/J.ULTSONCH.2010.11.023

Chen, K., Escott, C., Loira, I., del Fresno, J., Morata, A., Tesfaye, W., Calderon, F., Benito, S., SuárezLepe, J., 2016. The Effects of Pre-Fermentative Addition of Oenological Tannins on Wine Components and Sensorial Qualities of Red Wine. Molecules 21, 1445. https://doi.org/10.3390/molecules21111445

Cheng, V.J., Bekhit, A.E.-D.A., McConnell, M., Mros, S., Zhao, J., 2012. Effect of extraction solvent, waste fraction and grape variety on the antimicrobial and antioxidant activities of extracts from wine residue from cool climate. Food Chem. 134, 474-482. https://doi.org/10.1016/J.FOODCHEM.2012.02.103

Chowdhury, S.A., Vijayaraghavan, R., MacFarlane, D.R., 2010. Distillable ionic liquid extraction of tannins from plant materials. Green Chem. 12, 1023. https://doi.org/10.1039/b923248f

Chupin, L., Charrier, B., Pizzi, A., Perdomo, A., Charrier-El Bouhtoury, F., 2015. Study of thermal durability properties of tannin-lignosulfonate adhesives. J. Therm. Anal. Calorim. 119, 1577-1585. https://doi.org/10.1007/s10973-014-4331-0 
Chupin, L., Motillon, C., Charrier-El Bouhtoury, F., Pizzi, A., Charrier, B., 2013. Characterisation of maritime pine (Pinus pinaster) bark tannins extracted under different conditions by spectroscopic methods, FTIR and HPLC. Ind. Crops Prod. 49, 897-903. https://doi.org/10.1016/J.INDCROP.2013.06.045

Ciesla, W.M., 1998. Bark and Roots, in: Non-Wood Forest Products from Conifers. Food and Agriculture Organization of the United Nations, pp. 36-48.

Conde, E., Hemming, J., Smeds, A., Reinoso, B.D., Moure, A., Willför, S., Domínguez, H., Parajó, J.C., 2013. Extraction of low-molar-mass phenolics and lipophilic compounds from Pinus pinaster wood with compressed CO2. J. Supercrit. Fluids 81, 193-199. https://doi.org/10.1016/J.SUPFLU.2013.04.018

Ćurko, N., Tomašević, M., Cvjetko Bubalo, M., Gracin, L., Radojčić Redovniković, I., Kovačević Ganić, K., 2017. Extraction of Proanthocyanidins and Anthocyanins from Grape Skin by Using Ionic Liquids. Food Technol. Biotechnol. 55, 429-437. https://doi.org/10.17113/ftb.55.03.17.5200

Da Porto, C., Porretto, E., Decorti, D., 2013. Comparison of ultrasound-assisted extraction with conventional extraction methods of oil and polyphenols from grape (Vitis vinifera L.) seeds. Ultrason. Sonochem. 20, 1076-1080. https://doi.org/10.1016/J.ULTSONCH.2012.12.002

Dahmoune, F., Nayak, B., Moussi, K., Remini, H., Madani, K., 2015. Optimization of microwave-assisted extraction of polyphenols from Myrtus communis L. leaves. Food Chem. 166, 585-595. https://doi.org/10.1016/J.FOODCHEM.2014.06.066

Dahmoune, F., Spigno, G., Moussi, K., Remini, H., Cherbal, A., Madani, K., 2014. Pistacia lentiscus leaves as a source of phenolic compounds: Microwave-assisted extraction optimized and compared with ultrasound-assisted and conventional solvent extraction. Ind. Crops Prod. 61, 31-40. https://doi.org/10.1016/J.INDCROP.2014.06.035

Dai, J., Mumper, R.J., 2010. Plant Phenolics: Extraction, Analysis and Their Antioxidant and Anticancer Properties. Molecules 15, 7313-7352. https://doi.org/10.3390/molecules15107313

Dalzell, S.A., Kerven, G.L., 1998. A rapid method for the measurement ofLeucaena spp proanthocyanidins by the proanthocyanidin (butanol/HCl) assay. J. Sci. Food Agric. 78, 405-416. https://doi.org/10.1002/(SICI)1097-0010(199811)78:3<405::AID-JSFA133>3.0.CO;2-G

Deng, Y., Zhao, Y., Padilla-Zakour, O., Yang, G., 2015. Polyphenols, antioxidant and antimicrobial activities of leaf and bark extracts of Solidago canadensis L. Ind. Crops Prod. 74, 803-809. https://doi.org/10.1016/J.INDCROP.2015.06.014

Dhanani, T., Shah, S., Gajbhiye, N.A., Kumar, S., 2013. Effect of extraction methods on yield, phytochemical constituents and antioxidant activity of Withania somnifera. Arab. J. Chem. 10, S1193-S1199. https://doi.org/10.1016/J.ARABJC.2013.02.015

Diouf, P.N., Stevanovic, T., Boutin, Y., 2009. The effect of extraction process on polyphenol content, triterpene composition and bioactivity of yellow birch (Betula alleghaniensis Britton) extracts. Ind. Crops Prod. 30, 297-303. https://doi.org/10.1016/J.INDCROP.2009.05.008 
do Prado, A.C.P., da Silva, H.S., da Silveira, S.M., Barreto, P.L.M., Vieira, C.R.W., Maraschin, M., Ferreira, S.R.S., Block, J.M., 2014. Effect of the extraction process on the phenolic compounds profile and the antioxidant and antimicrobial activity of extracts of pecan nut [Carya illinoinensis (Wangenh) C. Koch] shell. Ind. Crops Prod. 52, 552-561. https://doi.org/10.1016/J.INDCROP.2013.11.031

Elsevier, 2016. Scopus Factsheet.

Erşan, S., Güçlü Üstündağ, Ö., Carle, R., Schweiggert, R.M., 2018. Subcritical water extraction of phenolic and antioxidant constituents from pistachio (Pistacia vera L.) hulls. Food Chem. 253, 46-54. https://doi.org/10.1016/J.FOODCHEM.2018.01.116

Fernandes, L., Casal, S.I.P., Pereira, J.A., Ramalhosa, E., Saraiva, J.A., 2017. Optimization of high pressure bioactive compounds extraction from pansies ( Viola $\times$ wittrockiana $)$ by response surface methodology. High Press. Res. 37, 415-429. https://doi.org/10.1080/08957959.2017.1347925

Frutos, P., Hervás, G., Giráldez, F.J., Mantecón, A.R., 2004. Review. Tannins and ruminant nutrition. Spanish J. Agric. Res. 2, 191. https://doi.org/10.5424/sjar/2004022-73

Gallo, M., Ferracane, R., Graziani, G., Ritieni, A., Fogliano, V., 2010. Microwave Assisted Extraction of Phenolic Compounds from Four Different Spices. Molecules 15, 6365-6374. https://doi.org/10.3390/molecules 15096365

García-Marino, M., Rivas-Gonzalo, J.C., Ibáñez, E., García-Moreno, C., 2006. Recovery of catechins and proanthocyanidins from winery by-products using subcritical water extraction. Anal. Chim. Acta 563, 44-50. https://doi.org/10.1016/J.ACA.2005.10.054

Geoffroy, T.R., Fortin, Y., Stevanovic, T., 2017. Hot-Water Extraction Optimization of Sugar Maple (Acer saccharum Marsh.) and Red Maple (Acer rubrum L.) Bark Applying Principal Component Analysis. J. Wood Chem. Technol. 37, 261-272. https://doi.org/10.1080/02773813.2017.1279631

Ghadage, D.M., Kshirsagar, P.R., Pai, S.R., Chavan, J.J., 2017. Extraction efficiency, phytochemical profiles and antioxidative properties of different parts of Saptarangi (Salacia chinensis L.) - An important underutilized plant. Biochem. Biophys. Reports 12, 79-90. https://doi.org/10.1016/J.BBREP.2017.08.012

Glombitza, K.-W., Pauli, K., 2003. Fucols and Phlorethols from the Brown Alga Scytothamnus australis Hook. et Harv. (Chnoosporaceae). Bot. Mar. 46, 315-320. https://doi.org/10.1515/BOT.2003.028

Goli, A.H., Barzegar, M., Sahari, M.A., 2005. Antioxidant activity and total phenolic compounds of pistachio (Pistachia vera) hull extracts. Food Chem. 92, 521-525. https://doi.org/10.1016/J.FOODCHEM.2004.08.020

Guo, Z., Jin, Q., Fan, G., Duan, Y., Qin, C., Wen, M., 2001. Microwave-assisted extraction of effective constituents from a Chinese herbal medicine Radix puerariae. Anal. Chim. Acta 436, 41-47. https://doi.org/10.1016/S0003-2670(01)00900-X

Hagerman, A.E., 2002. Tannin chemistry. Oxford. 
Hagerman, A.E., 1988. Extraction of tannin from fresh and preserved leaves. J. Chem. Ecol. 14, 453-461. https://doi.org/10.1007/BF01013897

Hartzfeld, P.W., Forkner, R., Hunter, M.D., Hagerman, A.E., 2002. Determination of Hydrolyzable Tannins (Gallotannins and Ellagitannins) after Reaction with Potassium Iodate. https://doi.org/10.1021/JF0111155

Haslam, E., 2007. Vegetable tannins - Lessons of a phytochemical lifetime. Phytochemistry 68, 27132721. https://doi.org/10.1016/J.PHYTOCHEM.2007.09.009

Hatano, T., Shida, S., Han, L., Okuda, T., 1991. Tannins of theaceous plants. III. Camelliatannins A and B, two new complex tannins from Camellia japonica L. Chem. Pharm. Bull. (Tokyo). 39, 876-880. https://doi.org/10.1248/cpb.39.876

Hernández-Fernández, F.J., Bayo, J., Pérez de los Ríos, A., Vicente, M.A., Bernal, F.J., Quesada-Medina, J., 2015. Discovering less toxic ionic liquids by using the Microtox® toxicity test. Ecotoxicol. Environ. Saf. 116, 29-33. https://doi.org/10.1016/J.ECOENV.2015.02.034

Hernes, P.J., Hedges, J.I., 2004. Tannin signatures of barks, needles, leaves, cones, and wood at the molecular level. Geochim. Cosmochim. Acta 68, 1293-1307. https://doi.org/10.1016/J.GCA.2003.09.015

Hong, N., Yaylayan, V.A., Vijaya Raghavan, G.S., Paré, J.R.J., Bélanger, J.M.R., 2001. Microwaveassisted Extraction of Phenolic Compounds from Grape Seed. Nat. Prod. Lett. 15, 197-204. https://doi.org/10.1080/10575630108041280

Huang, Z., Ye, C., Li, L., Zhang, X., Qiu, T., Huang, Z., Ye, C., Li, L., Zhang, X., Qiu, T., 2016. Measurement and correlation of the mass transfer coefficient for a liquid-liquid system with high density difference. Brazilian J. Chem. Eng. 33, 897-906. https://doi.org/10.1590/0104$6632.20160334 \mathrm{~s} 20150488$

Huma, Z.-E., Jayasena, V., Nasar-Abbas, S.M., Imran, M., Khan, M.K., 2018. Process optimization of polyphenol extraction from carob (Ceratonia siliqua) kibbles using microwave-assisted technique. J. Food Process. Preserv. 42, e13450. https://doi.org/10.1111/jfpp.13450

Hümmer, W., Schreier, P., 2008. Analysis of proanthocyanidins. Mol. Nutr. Food Res. 52, 1381-1398. https://doi.org/10.1002/mnfr.200700463

Inoue, S., Asaga, M., Ogi, T., Yazaki, Y., 1998. Extraction of Polyflavanoids from Radiata Pine Bark Using Hot Compressed Water at Temperatures Higher than $100{ }^{\circ} \mathrm{C}$. Holzforschung 52, 139-145. https://doi.org/10.1515/hfsg.1998.52.2.139

Ismail, T., Calcabrini, C., Diaz, A.R., Fimognari, C., Turrini, E., Catanzaro, E., Akhtar, S., Sestili, P., 2016. Ellagitannins in Cancer Chemoprevention and Therapy. Toxins (Basel). 8. https://doi.org/10.3390/TOXINS8050151

Ivanovic, J., Tadic, V., Dimitrijevic, S., Stamenic, M., Petrovic, S., Zizovic, I., 2014. Antioxidant properties of the anthocyanin-containing ultrasonic extract from blackberry cultivar “Čačanska Bestrna.” Ind. 
Crops Prod. 53, 274-281. https://doi.org/10.1016/J.INDCROP.2013.12.048

Jackson, F.S., McNabb, W.C., Barry, T.N., Foo, Y.L., Peters, J.S., 1996. The Condensed Tannin Content of a Range of Subtropical and Temperate Forages and the Reactivity of Condensed Tannin with Ribulose- 1,5-bis-phosphate Carboxylase (Rubisco) Protein. J. Sci. Food Agric. 72, 483-492. https://doi.org/10.1002/(SICI)1097-0010(199612)72:4<483::AID-JSFA684>3.0.CO;2-G

Jahanshaei, S., Tabarsa, T., Asghari, J., 2012. Eco-friendly tannin-phenol formaldehyde resin for producing wood composites. Pigment Resin Technol. 41, 296-301. https://doi.org/10.1108/03699421211264857

Jain, R., Bhagchandani, T., Yadav, N., 2013. An efficient and simple methodology coupling microwave assisted extraction to GC-MS for the identification of components in root bark of Guazuma tomentosa. Int. J. Pharma Bio Sci. 4, 520-533.

Jensen, W.B., 2007. The Origin of the Soxhlet Extractor. J. Chem. Educ. 84, 1913. https://doi.org/10.1021/ed084p1913

Jin, Z.-X., Wang, B.-Q., Chen, Z.-J., 2010. Microwave-assisted extraction of tannins from Chinese herb Agrimonia pilosa Ledeb. J. Med. Plants Res. 4, 2229-2234. https://doi.org/10.5897/JMPR10.378

Kaur, B., Kaur, N., 2016. Metabolic fingerprinting of different populations of Phyllanthus niruri L. from Punjab using electrospray ionization mass spectrometry (ESI-MS). Med. Chem. Res. 25, 2798-2821. https://doi.org/10.1007/s00044-016-1674-z

Kemppainen, K., Siika-aho, M., Pattathil, S., Giovando, S., Kruus, K., 2014. Spruce bark as an industrial source of condensed tannins and non-cellulosic sugars. Ind. Crops Prod. 52, 158-168. https://doi.org/10.1016/J.INDCROP.2013.10.009

Khoddami, A., Wilkes, M.A., Roberts, T.H., 2013. Techniques for Analysis of Plant Phenolic Compounds. Molecules 18, 2328-2375. https://doi.org/10.3390/molecules18022328

Kirke, D.A., Smyth, T.J., Rai, D.K., Kenny, O., Stengel, D.B., 2017. The chemical and antioxidant stability of isolated low molecular weight phlorotannins. Food Chem. 221, 1104-1112. https://doi.org/10.1016/J.FOODCHEM.2016.11.050

Koivikko, R., Eränen, J.K., Loponen, J., Jormalainen, V., 2008. Variation of Phlorotannins Among Three Populations of Fucus vesiculosus as Revealed by HPLC and Colorimetric Quantification. J. Chem. Ecol. 34, 57-64. https://doi.org/10.1007/s10886-007-9410-2

Landete, J.M., 2011. Ellagitannins, ellagic acid and their derived metabolites: A review about source, metabolism, functions and health. Food Res. Int. 44, 1150-1160. https://doi.org/10.1016/J.FOODRES.2011.04.027

Laurichesse, S., Avérous, L., 2014. Chemical modification of lignins: Towards biobased polymers. Prog. Polym. Sci. 39, 1266-1290. https://doi.org/10.1016/J.PROGPOLYMSCI.2013.11.004

Li, Y., Skouroumounis, G.K., Elsey, G.M., Taylor, D.K., 2011. Microwave-assistance provides very rapid and efficient extraction of grape seed polyphenols. Food Chem. 129, 570-576. 
https://doi.org/10.1016/J.FOODCHEM.2011.04.068

Liang, X., Fan, Q., 2013. Application of Sub-Critical Water Extraction in Pharmaceutical Industry. J. Mater.

Sci. Chem. Eng. 1, 1-6. https://doi.org/10.4236/msce.2013.15001

Liu, C., Hu, J., Zhang, H., Xiao, R., 2016. Thermal conversion of lignin to phenols: Relevance between chemical structure and pyrolysis behaviors. Fuel 182, 864-870. https://doi.org/10.1016/J.FUEL.2016.05.104

Liu, Z., Chen, Z., Han, F., Kang, X., Gu, H., Yang, L., 2016. Microwave-assisted method for simultaneous hydrolysis and extraction in obtaining ellagic acid, gallic acid and essential oil from Eucalyptus globulus leaves using Brönsted acidic ionic liquid [HO3S(CH2)4mim]HSO4. Ind. Crops Prod. 81, 152-161. https://doi.org/10.1016/J.INDCROP.2015.11.074

Lochab, B., Shukla, S., Varma, I.K., 2014. Naturally occurring phenolic sources: monomers and polymers. RSC Adv. 4, 21712-21752. https://doi.org/10.1039/C4RA00181H

Lopes, G., Sousa, C., Silva, L.R., Pinto, E., Andrade, P.B., Bernardo, J., Mouga, T., Valentão, P., 2012. Can phlorotannins purified extracts constitute a novel pharmacological alternative for microbial infections with associated inflammatory conditions? PLoS One 7, e31145. https://doi.org/10.1371/journal.pone.0031145

Lu, C., Wang, H., Lv, W., Ma, C., Lou, Z., Xie, J., Liu, B., 2012. Ionic liquid-based ultrasonic/microwaveassisted extraction combined with UPLC-MS-MS for the determination of tannins in Galla chinensis. Nat. Prod. Res. 26, 1842-1847. https://doi.org/10.1080/14786419.2011.607454

Luengthanaphol, S., Mongkholkhajornsilp, D., Douglas, S., Douglas, P.L., Pengsopa, L., Pongamphai, S., 2004. Extraction of antioxidants from sweet Thai tamarind seed coat—preliminary experiments. J. Food Eng. 63, 247-252. https://doi.org/10.1016/J.JFOODENG.2003.07.006

Luque de Castro, M.D., Priego-Capote, F., 2010. Soxhlet extraction: Past and present panacea. J. Chromatogr. A 1217, 2383-2389. https://doi.org/10.1016/J.CHROMA.2009.11.027

Mailoa, M.N., Mahendradatta, M., Laga, A., Djide, N., 2013. Tannin extract of guava leaves (Psidium guajava L) variation with concentration organic solvents. Int. J. Sci. Technol. Res. 2, 106-110. https://doi.org/10.1023/A:1026206511084

Mangan, J.L., 1988. Nutritional Effects of Tannins in Animal Feeds. Nutr. Res. Rev. 1, 209. https://doi.org/10.1079/NRR19880015

Maran, J.P., Manikandan, S., Priya, B., Gurumoorthi, P., 2015. Box-Behnken design based multi-response analysis and optimization of supercritical carbon dioxide extraction of bioactive flavonoid compounds from tea (Camellia sinensis L.) leaves. J. Food Sci. Technol. 52, 92-104. https://doi.org/10.1007/s13197-013-0985-z

Markom, M., Hasan, M., Daud, W.R.W., 2010a. Pressurized Water Extraction of Hydrolysable Tannins from Phyllanthus niruri Linn. Sep. Sci. Technol. 45, 548-553. https://doi.org/10.1080/01496390903485005 
Markom, M., Hasan, M., Daud, W.R.W., Anuar, N., Hassan, O., Singh, H., 2010b. Chemical Profiling and Quantification of Tannins in Phyllanthus niruri Linn. Fractionated by SFE Method. Sep. Sci. Technol. 46, 71-78. https://doi.org/10.1080/01496395.2010.498005

Markom, M., Hasan, M., Daud, W.R.W., Singh, H., Jahim, J.M., 2007. Extraction of hydrolysable tannins from Phyllanthus niruri Linn.: Effects of solvents and extraction methods. Sep. Purif. Technol. 52, 487-496. https://doi.org/10.1016/J.SEPPUR.2006.06.003

Mašković, P.Z., Veličković, V., Đurović, S., Zeković, Z., Radojković, M., Cvetanović, A., Švarc-Gajić, J., Mitić, M., Vujić, J., 2018. Biological activity and chemical profile of Lavatera thuringiaca L. extracts obtained by different extraction approaches. Phytomedicine 38, 118-124. https://doi.org/10.1016/J.PHYMED.2017.11.010

Mattivi, F., Vrhovsek, U., Masuero, D., Trainotti, D., 2009. Differences in the amount and structure of extractable skin and seed tannins amongst red grape varieties. Aust. J. Grape Wine Res. 15, 27-35. https://doi.org/10.1111/j.1755-0238.2008.00027.x

McGraw, G.W., 1989. Reactions at the A-ring of Proanthocyanidins, in: Chemistry and Significance of Condensed Tannins. Springer US, Boston, MA, pp. 227-248. https://doi.org/10.1007/978-1-46847511-1_14

Murugan, R., Parimelazhagan, T., 2014. Comparative evaluation of different extraction methods for antioxidant and anti-inflammatory properties from Osbeckia parvifolia Arn. - An in vitro approach. J. King Saud Univ. - Sci. 26, 267-275. https://doi.org/10.1016/J.JKSUS.2013.09.006

Myers, M.L., 1998. Agriculture and Natural Resources Based Industries, in: Encyclopaedia of Occupational Health and Safety. International Labour Organization.

Naima, R., Oumam, M., Hannache, H., Sesbou, A., Charrier, B., Pizzi, A., Charrier - El Bouhtoury, F., 2015. Comparison of the impact of different extraction methods on polyphenols yields and tannins extracted from Moroccan Acacia mollissima barks. Ind. Crops Prod. 70, 245-252. https://doi.org/10.1016/J.INDCROP.2015.03.016

Olivier-Bourbigou, H., Magna, L., Morvan, D., 2010. Ionic liquids and catalysis: Recent progress from knowledge to applications. Appl. Catal. A Gen. 373, 1-56. https://doi.org/10.1016/J.APCATA.2009.10.008

Palmer, M.V., Ting, S.S.T., 1995. Applications for supercritical fluid technology in food processing. Food Chem. 52, 345-352. https://doi.org/10.1016/0308-8146(95)93280-5

Pan, Y., He, C., Wang, H., Ji, X., Wang, K., Liu, P., 2010. Antioxidant activity of microwave-assisted extract of Buddleia officinalis and its major active component. Food Chem. 121, 497-502. https://doi.org/10.1016/J.FOODCHEM.2009.12.072

Panamgama, L.A., 2007. Polyphenolic extracts ofPinus radiata bark and networking mechanisms of additive-accelerated polycondensates. J. Appl. Polym. Sci. 103, 2487-2493. https://doi.org/10.1002/app.24466 
Pansera, M.R., Iob, G.A., Atti-Santos, A.C., Rossato, M., Atti-Serafini, L., Cassel, E., 2004. Extraction of tannin by Acacia mearnsii with supercritical fluids. Brazilian Arch. Biol. Technol. 47, 995-998. https://doi.org/10.1590/S1516-89132004000600019

Park, M., Cho, H., Jung, H., Lee, H., Hwang, K.T., 2014. Antioxidant and Anti-Inflammatory Activities of Tannin Fraction of the Extract from Black Raspberry Seeds Compared to Grape Seeds. J. Food Biochem. 38, 259-270. https://doi.org/10.1111/jfbc.12044

Pereira, P., Cebola, M.-J., Oliveira, M.C., Bernardo-Gil, M.G., 2016. Supercritical fluid extraction vs conventional extraction of myrtle leaves and berries: Comparison of antioxidant activity and identification of bioactive compounds. J. Supercrit. Fluids 113, 1-9. https://doi.org/10.1016/J.SUPFLU.2015.09.006

Pereira, P., Cebola, M.-J., Oliveira, M.C., Bernardo Gil, M.G., 2017. Antioxidant capacity and identification of bioactive compounds of Myrtus communis L. extract obtained by ultrasound-assisted extraction. J. Food Sci. Technol. 54, 4362-4369. https://doi.org/10.1007/s13197-017-2907-y

Perrut†, M., 2000. Supercritical Fluid Applications: Industrial Developments and Economic Issues. https://doi.org/10.1021/IE000211C

Ping, L., Brosse, N., Chrusciel, L., Navarrete, P., Pizzi, A., 2011. Extraction of condensed tannins from grape pomace for use as wood adhesives. Ind. Crops Prod. 33, 253-257. https://doi.org/10.1016/J.INDCROP.2010.10.007

Plaza, M., Amigo-Benavent, M., del Castillo, M.D., Ibáñez, E., Herrero, M., 2010. Facts about the formation of new antioxidants in natural samples after subcritical water extraction. Food Res. Int. 43, 2341-2348. https://doi.org/10.1016/J.FOODRES.2010.07.036

Plaza, M., Turner, C., 2015. Pressurized hot water extraction of bioactives. TrAC Trends Anal. Chem. 71, 39-54. https://doi.org/10.1016/J.TRAC.2015.02.022

Politi, F.A.S., de Mello, J.C.P., Migliato, K.F., Nepomuceno, A.L.A., Moreira, R.R.D., Pietro, R.C.L.R., 2011. Antimicrobial, cytotoxic and antioxidant activities and determination of the total tannin content of bark extracts Endopleura uchi. Int. J. Mol. Sci. 12, 2757-68. https://doi.org/10.3390/ijms12042757

Poveda, J.M., Loarce, L., Alarcón, M., Díaz-Maroto, M.C., Alañón, M.E., 2018. Revalorization of winery by-products as source of natural preservatives obtained by means of green extraction techniques. Ind. Crops Prod. 112, 617-625. https://doi.org/10.1016/J.INDCROP.2017.12.063

Ramires, E.C., Frollini, E., 2012. Tannin-phenolic resins: Synthesis, characterization, and application as matrix in biobased composites reinforced with sisal fibers. Compos. Part B Eng. 43, 2851-2860. https://doi.org/10.1016/J.COMPOSITESB.2012.04.049

Ramos, V., Bocalandro, C., Riquelme, S., Sanhueza, V., Aspé, E., Roeckel, M., Fernández, K., 2013. Effect of the bench scale extraction conditions on Pinus radiata bark extract yield, antioxidant properties and composition. Maderas. Cienc. y Tecnol. 15, 0-0. https://doi.org/10.4067/S0718$221 \times 2013005000003$ 
Rangsriwong, P., Rangkadilok, N., Satayavivad, J., Goto, M., Shotipruk, A., 2009. Subcritical water extraction of polyphenolic compounds from Terminalia chebula Retz. fruits. Sep. Purif. Technol. 66, 51-56. https://doi.org/10.1016/J.SEPPUR.2008.11.023

Ravber, M., Knez, Ž., Škerget, M., 2015. Isolation of phenolic compounds from larch wood waste using pressurized hot water: extraction, analysis and economic evaluation. Cellulose 22, 3359-3375. https://doi.org/10.1007/s10570-015-0719-7

Reátegui, J.L.P., Machado, A.P. da F., Barbero, G.F., Rezende, C.A., Martínez, J., 2014. Extraction of antioxidant compounds from blackberry (Rubus sp.) bagasse using supercritical CO2 assisted by ultrasound. J. Supercrit. Fluids 94, 223-233. https://doi.org/10.1016/J.SUPFLU.2014.07.019

Ribeiro, B.D., Coelho, M.A.Z., Rebelo, L.P.N., Marrucho, I.M., 2013. Ionic Liquids as Additives for Extraction of Saponins and Polyphenols from Mate (Ilex paraguariensis) and Tea (Camellia sinensis). Ind. Eng. Chem. Res. 52, 12146-12153. https://doi.org/10.1021/ie400529h

Routray, W., Orsat, V., 2012. Microwave-Assisted Extraction of Flavonoids: A Review. Food Bioprocess Technol. 5, 409-424. https://doi.org/10.1007/s11947-011-0573-z

Saad, H., Charrier-El Bouhtoury, F., Pizzi, A., Rode, K., Charrier, B., Ayed, N., 2012. Characterization of pomegranate peels tannin extractives. Ind. Crops Prod. 40, 239-246. https://doi.org/10.1016/J.INDCROP.2012.02.038

Sathya, R., Kanaga, N., Sankar, P., Jeeva, S., 2017. Antioxidant properties of phlorotannins from brown seaweed Cystoseira trinodis (Forsskål) C. Agardh. Arab. J. Chem. 10, S2608-S2614. https://doi.org/10.1016/J.ARABJC.2013.09.039

Saxena, R., Sharma, R., Nandy, C., Jasuja, N.D., 2014. Qualitative and quantitative estiamtion of bioactive compounds in mimosa hamata. Int. J. Pharm. Pharm. Sci. 6.

Sealy-Fisher, V.J., Pizzi, A., 1992. Increased pine tannins extraction and wood adhesives development by phlobaphenes minimization. Holz als Roh- und Werkst. 50, 212-220. https://doi.org/10.1007/BF02663290

Selvamuthukumaran, M., Shi, J., 2017. Recent advances in extraction of antioxidants from plant byproducts processing industries. Food Qual. Saf. 1, 61-81. https://doi.org/10.1093/fqsafe/fyx004

Sousa, A.D., Maia, A.I.V., Rodrigues, T.H.S., Canuto, K.M., Ribeiro, P.R.V., de Cassia Alves Pereira, R., Vieira, R.F., de Brito, E.S., 2016. Ultrasound-assisted and pressurized liquid extraction of phenolic compounds from Phyllanthus amarus and its composition evaluation by UPLC-QTOF. Ind. Crops Prod. 79, 91-103. https://doi.org/10.1016/J.INDCROP.2015.10.045

Švarc-Gajić, J., Stojanović, Z., Segura Carretero, A., Arráez Román, D., Borrás, I., Vasiljević, I., 2013. Development of a microwave-assisted extraction for the analysis of phenolic compounds from $\begin{array}{lllll}\text { Rosmarinus } & \text { officinalis. } & \text { J. } & \text { Food } & \text { Eng. }\end{array}$ https://doi.org/10.1016/J.JFOODENG.2013.06.030

Tabaraki, R., Safari, A., Yeganeh, F.A., 2013. Ultrasonic-assisted extraction of condensed tannin from 
acron, gland, leaf and gall of oak using response surface methodology. J. Appl. Chem. Res. 7, 67-77.

Talmaciu, A.I., Ravber, M., Volf, I., Knez, Ž., Popa, V.I., 2016. Isolation of bioactive compounds from spruce bark waste using sub- and supercritical fluids. J. Supercrit. Fluids 117, 243-251. https://doi.org/10.1016/J.SUPFLU.2016.07.001

Tan, M.., Tan, C.., Ho, C.., 2013. Effects of extraction solvent system, time and temperature on total phenolic content of henna (Lawsonia inermis) stems. Int. Food Res. J. 20, 3117-3123.

Thomson Reuters, 2013. Web of Science Factsheet.

Vázquez, G., González-Alvarez, J., Freire, S., López-Suevos, F., Antorrena, G., 2001. Characteristics of Pinus pinaster bark extracts obtained under various extraction conditions. Holz als Roh- und Werkst. 59, 451-456. https://doi.org/10.1007/s00107-001-0246-0

Veggi, P.C., Cavalcanti, R.N., Meireles, M.A.A., 2011. Modifier effects on Supercritical Fluid Extraction (SFE) of some Brazilian plants: Antioxidant activity and Economical evaluation. Procedia Food Sci. 1, 1717-1724. https://doi.org/10.1016/J.PROFOO.2011.09.253

Veličković, V., Đurović, S., Radojković, M., Cvetanović, A., Švarc-Gajić, J., Vujić, J., Trifunović, S., Mašković, P.Z., 2017. Application of conventional and non-conventional extraction approaches for extraction of Erica carnea L.: Chemical profile and biological activity of obtained extracts. J. Supercrit. Fluids 128, 331-337. https://doi.org/10.1016/J.SUPFLU.2017.03.023

Vergara-Salinas, J.R., Bulnes, P., Zúñiga, M.C., Pérez-Jiménez, J., Torres, J.L., Mateos-Martín, M.L., Agosin, E., Pérez-Correa, J.R., 2013. Effect of Pressurized Hot Water Extraction on Antioxidants from Grape Pomace before and after Enological Fermentation. J. Agric. Food Chem. 61, 6929-6936. https://doi.org/10.1021/jf4010143

Vieira, M.C., Lelis, R.C.C., Couto Da Silva, B., De, G., Oliveira, L., De Pesquisa, A., 2011. Tannin Extraction from the Bark of Pinus oocarpa var. oocarpa with Sodium Carbonate and Sodium Bisulfite. Floresta e Ambient. 18, 1-81. https://doi.org/10.4322/floram.2011.017

Vijayalaxmi, S., Jayalakshmi, S.K., Sreeramulu, K., 2015. Polyphenols from different agricultural residues: extraction, identification and their antioxidant properties. J. Food Sci. Technol. 52, 2761-2769. https://doi.org/10.1007/s13197-014-1295-9

Wang, Y.-L., Xi, G.-S., Zheng, Y.-C., Miao, F.-S., 2010. Microwave-assisted extraction of flavonoids from Chinese herb Radix puerariae (Ge Gen). J. Med. Plants Res. 4, 304-308. https://doi.org/10.5897/JMPR09.426

Widyawati, P.S., Dwi, T., Budianta, W., Kusuma, F.A., Wijaya, E.L., 2014. Difference of Solvent Polarity To Phytochemical Content and Antioxidant Activity of Pluchea indicia Less Leaves Extracts. Int. J. Pharmacogn. Phytochem. Res. 6, 850-855.

Wohlin, C., Claes, 2014. Guidelines for snowballing in systematic literature studies and a replication in software engineering, in: Proceedings of the 18th International Conference on Evaluation and Assessment in Software Engineering - EASE '14. ACM Press, New York, New York, USA, pp. 1- 
10. https://doi.org/10.1145/2601248.2601268

Xiao, W., Han, L., Shi, B., 2008. Microwave-assisted extraction of flavonoids from Radix Astragali. Sep. Purif. Technol. 62, 614-618. https://doi.org/10.1016/J.SEPPUR.2008.03.025

Xu, C.-C., Wang, B., Pu, Y.-Q., Tao, J.-S., Zhang, T., 2017. Advances in extraction and analysis of phenolic compounds from plant materials. Chin. J. Nat. Med. 15, 721-731. https://doi.org/10.1016/S18755364(17)30103-6 


\section{LIST OF FIGURES:}

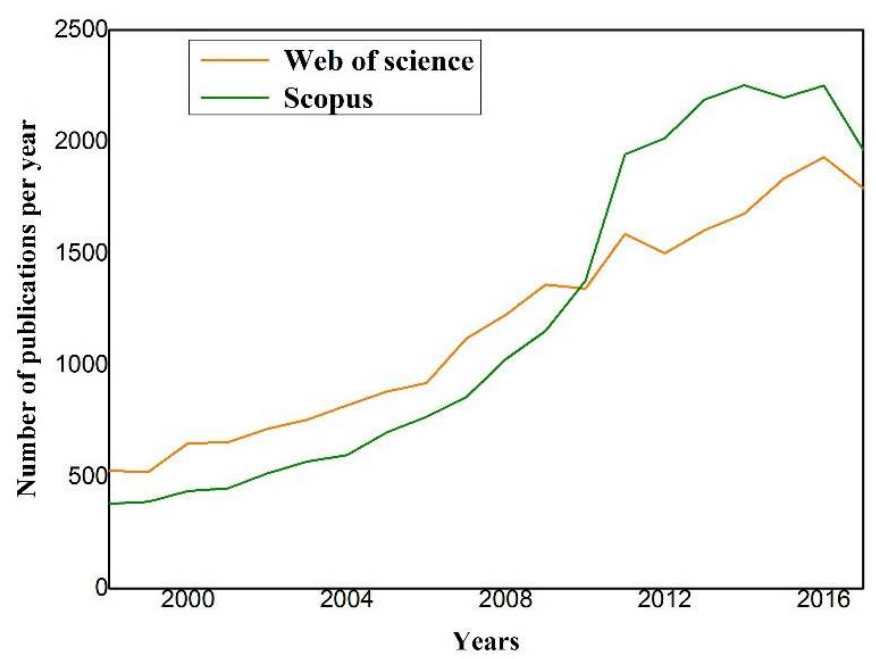

Figure 1. Number of tannins-related publications per year in the period 1998-2017 indexed in Web-ofScience and Scopus.

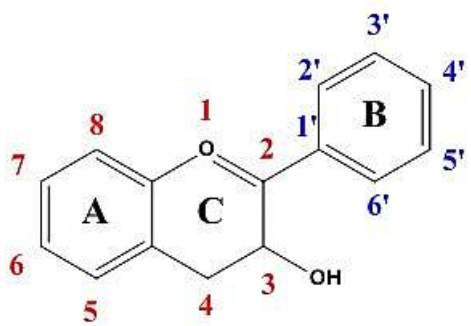

Figure 2. Structure of Flavan-3-ol and its nomenclature

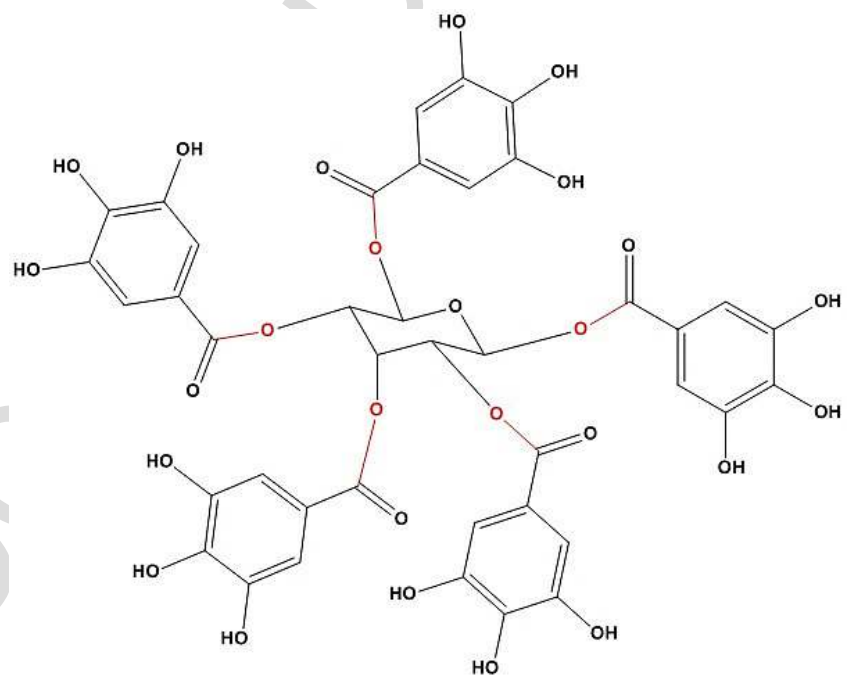

Figure 3. Example of a hydrolysable tannin unit and the linkages present (e.g. pentagalloyl glucose structure linked via ester bonds). 


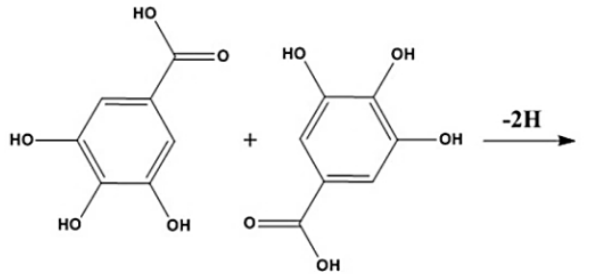

2 gallic acid

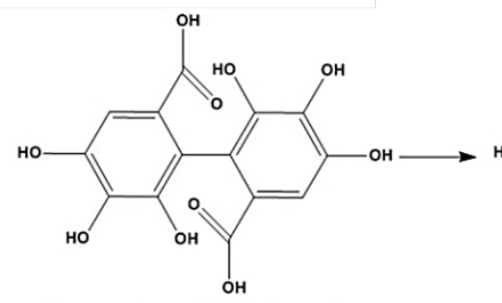

Hexahydroxydiphenic acid

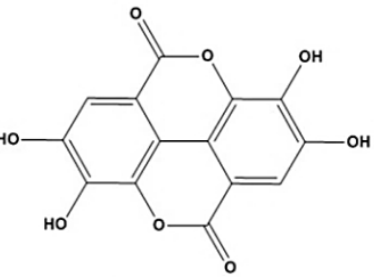

Ellagic acid (HHDP)

Figure 4. Transformation between the main polyphenolic acids and derivatives present in the structure of hydrolysable tannins

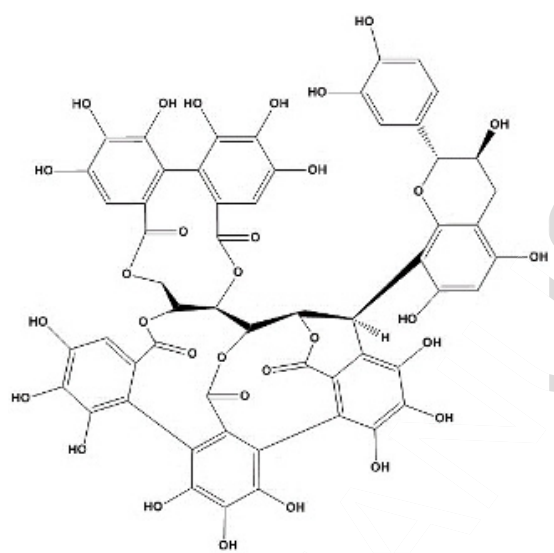

Figure 5. Acutissimin A typical complex tannins group.

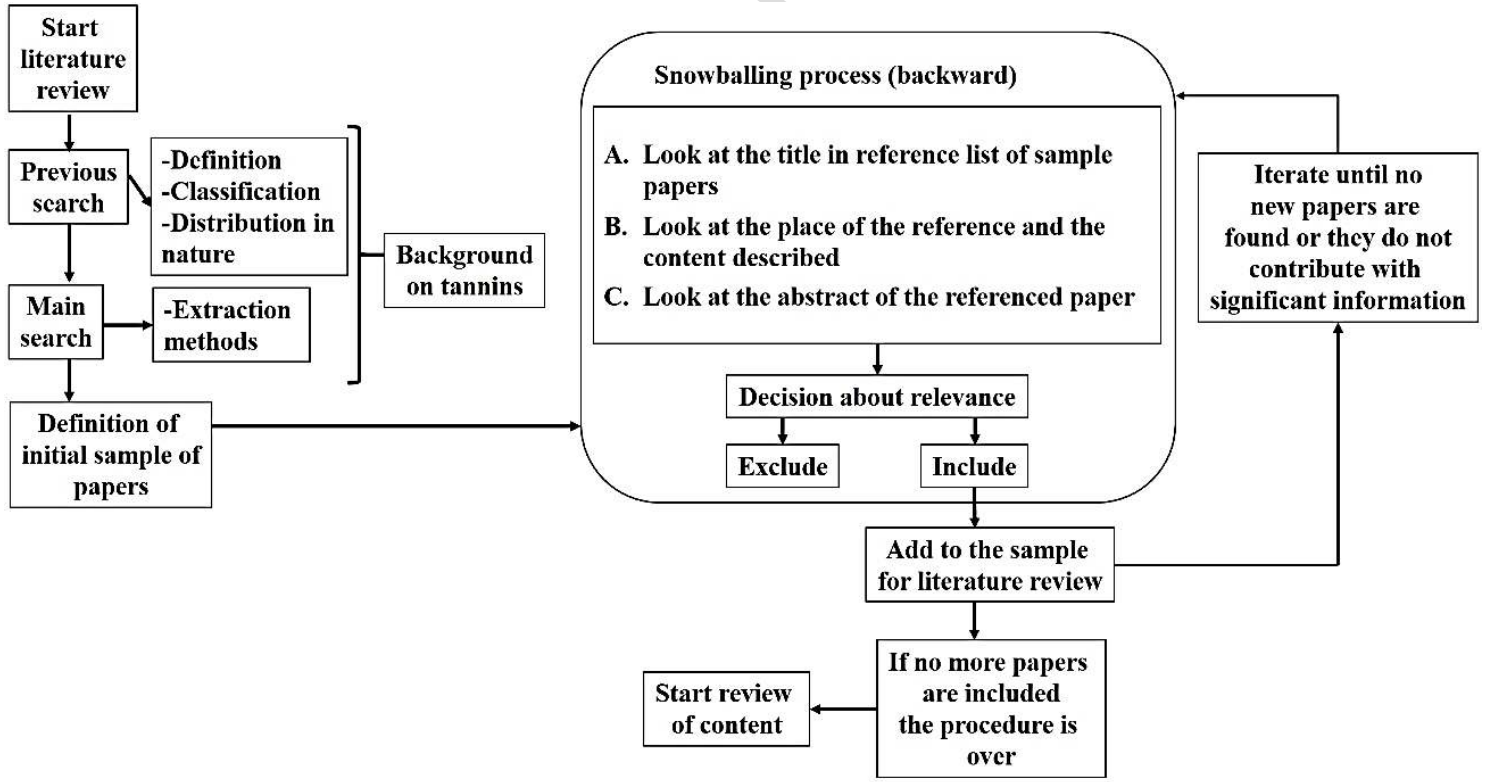

Figure 6. Literature review process 


\section{LIST OF TABLES:}

Table 1. Structures of the most common flavan-3-ol monomers of condensed tannins

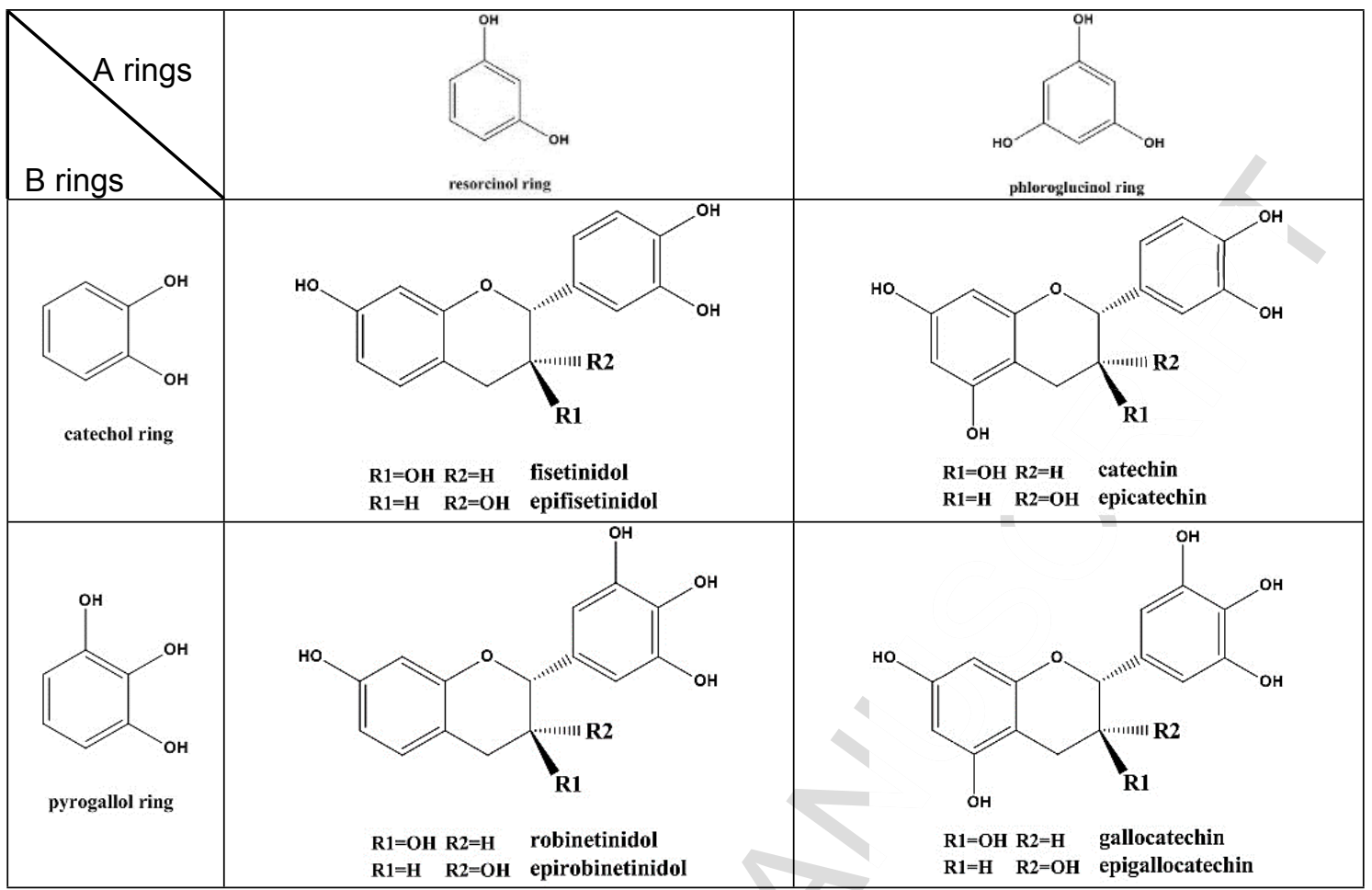

Table 2. Strings and number of results obtained for the individual search of each tannin extraction method

\begin{tabular}{|c|c|c|}
\hline \multirow{2}{*}{ SEARCH STRINGS } & \multicolumn{2}{|c|}{ NUMBER OF RESULTS } \\
\hline & SCOPUS & WEB OF SCIENCE \\
\hline [organic solvent extraction AND tannin] & 117 & 111 \\
\hline [hot water extraction AND tannin] & 73 & 80 \\
\hline [ionic liquid extraction AND tannin] & 9 & 12 \\
\hline [supercritical fluid extraction AND tannin] & 31 & 46 \\
\hline [pressurized water extraction AND tannin] & 13 & 17 \\
\hline [subcritical water extraction AND tannin] & 7 & 11 \\
\hline [microwave assisted extraction AND tannin] & 35 & 48 \\
\hline [ultrasound assisted extraction AND tannin] & 36 & 50 \\
\hline
\end{tabular}


Table 3. Results related to the tannins solid-liquid extraction with different solvents

\begin{tabular}{|c|c|c|c|c|c|c|}
\hline Species & $\begin{array}{c}\text { Plant } \\
\text { part }\end{array}$ & Solvent & $\begin{array}{l}\text { Extraction } \\
\text { conditions }\end{array}$ & $\begin{array}{l}\text { Extraction } \\
\text { Yield } \\
(\% \mathrm{w} / \mathrm{w})^{\mathrm{a}}\end{array}$ & $\begin{array}{l}\text { Tannin content } \\
\left(\mathrm{mg} / \mathrm{g}_{\mathrm{DE}} \mathrm{b}\right)\end{array}$ & References \\
\hline \multirow{2}{*}{$\begin{array}{l}\text { Pinus } \\
\text { radiata }\end{array}$} & \multirow{2}{*}{ Bark } & Water & \multirow{2}{*}{$\begin{array}{c}1: 20,2 \mathrm{~h} \\
100^{\circ} \mathrm{C}\end{array}$} & 19.60 & $887.00^{\mathrm{c}}$ & \multirow{2}{*}{$\begin{array}{c}\text { (Inoue et al., } \\
1998) \\
\end{array}$} \\
\hline & & Water+ $1 \% \mathrm{NaOH}$ & & 30.50 & $828.00^{\mathrm{c}}$ & \\
\hline \multirow{4}{*}{$\begin{array}{c}\text { Pinus } \\
\text { pinaster }\end{array}$} & \multirow{4}{*}{ Bark } & Water $+2.5 \% \mathrm{NaOH}$ & \multirow{2}{*}{$\begin{array}{c}1: 10,0.5 \mathrm{~h} \\
70^{\circ} \mathrm{C}\end{array}$} & 16.5 & $965.00^{\mathrm{c}}$ & \multirow{4}{*}{$\begin{array}{l}\text { (Vázquez et al., } \\
\text { 2001) }\end{array}$} \\
\hline & & Water $+5 \% \mathrm{NaOH}$ & & 18.9 & $875.00^{\mathrm{c}}$ & \\
\hline & & Water $+2.5 \% \mathrm{NaOH}$ & \multirow{2}{*}{$\begin{array}{c}1: 10,0.5 \mathrm{~h} \\
90^{\circ} \mathrm{C}\end{array}$} & 23.20 & $963.00^{\mathrm{c}}$ & \\
\hline & & Water $+5 \% \mathrm{NaOH}$ & & 25.00 & $812.00^{c}$ & \\
\hline \multirow{2}{*}{$\begin{array}{l}\text { Mangifera } \\
\text { indica }\end{array}$} & Peels & \multirow{2}{*}{$\begin{array}{l}\text { Acetone } \\
(80 \%)\end{array}$} & \multirow[b]{2}{*}{$1: 20,3 \mathrm{~h}$} & \multirow[b]{2}{*}{---} & $1.4^{\mathrm{d}}$ & \multirow{2}{*}{$\begin{array}{c}\text { (Berardini et al., } \\
\text { 2004) }\end{array}$} \\
\hline & Pulp & & & & $\frac{0.2^{\mathrm{d}}}{15.5 \mathrm{~d}}$ & \\
\hline Acacia & Kernel & & & & $15.5^{4}$ & (Pansera et al \\
\hline mearnsii & Bark & Ethanol & $1: 10,24 \mathrm{~h}$ & --- & $237.00^{\mathrm{e}}$ & 2004) \\
\hline \multirow{3}{*}{$\begin{array}{c}\text { Phyllanthus } \\
\text { niruri }\end{array}$} & \multirow{3}{*}{$\begin{array}{l}\text { Stem } \\
\text { and } \\
\text { aerial } \\
\text { parts }\end{array}$} & Water & \multirow{3}{*}{$\begin{array}{c}1: 30,3 \mathrm{~h} \\
\text { b.p }\end{array}$} & 26.2 & $215.90^{\mathrm{f}}$ & \multirow{3}{*}{$\begin{array}{c}\text { (Markom et al., } \\
\text { 2007) }\end{array}$} \\
\hline & & Ethanol $(50 \%)$ & & 22.50 & $149.00^{f}$ & \\
\hline & & Ethanol $(70 \%)$ & & 20.80 & $91.10^{\mathrm{f}}$ & \\
\hline \multirow[t]{4}{*}{$\begin{array}{l}\text { Acacia } \\
\text { catechu }\end{array}$} & \multirow{4}{*}{$\begin{array}{l}\text { Whole } \\
\text { plant }\end{array}$} & \multirow{3}{*}{$\begin{array}{c}\text { N,N- } \\
\text { dimethylammonium } \\
\text { N',N'- } \\
\text { dimethylcarbamate } \\
\text { (DIMCARB) }(15 \%)\end{array}$} & $\begin{array}{c}1: 5,25^{\circ} \mathrm{C} \\
1 \mathrm{~h}\end{array}$ & 30 & --- & \multirow{4}{*}{$\begin{array}{l}\text { (Chowdhury et } \\
\text { al., 2010) }\end{array}$} \\
\hline & & & $\begin{array}{c}1: 5,25^{\circ} \mathrm{C} \\
2 \mathrm{~h} \\
\end{array}$ & 60 & --- & \\
\hline & & & $\begin{array}{c}1: 5,25^{\circ} \mathrm{C} \\
16 \mathrm{~h} \\
\end{array}$ & 85 & $61.50^{\mathrm{f}}$ & \\
\hline & & Water & $\begin{array}{c}1: 10,70^{\circ} \mathrm{C} \\
16 \mathrm{~h} \\
\end{array}$ & 64 & $28.60^{\mathrm{f}}$ & \\
\hline $\begin{array}{l}\text { Pinus } \\
\text { radiata }\end{array}$ & Bark & Acetone $(70 \%)$ & $1: 10,1-6 h$ & 12.00 & $62.10^{\mathrm{h}}$ & $\begin{array}{c}\text { (Aspé and } \\
\text { Fernández, 2011) }\end{array}$ \\
\hline \multirow{3}{*}{ Vitis vinifera } & \multirow{3}{*}{ Pomace } & Water $+10 \% \mathrm{NaOH}$ & \multirow{3}{*}{$\begin{array}{l}1: 8,2 \mathrm{~h} \\
120^{\circ} \mathrm{C}\end{array}$} & 45.20 & $550.00^{\mathrm{c}}$ & \multirow{3}{*}{ (Ping et al., 2011) } \\
\hline & & Water $+20 \% \mathrm{NaOH}$ & & 71.10 & $490.00^{\mathrm{c}}$ & \\
\hline & & Water $+30 \% \mathrm{NaOH}$ & & 88.40 & $390.00^{\mathrm{c}}$ & \\
\hline \multirow{3}{*}{$\begin{array}{c}\text { Endopleura } \\
\text { uchi }\end{array}$} & \multirow{3}{*}{ Bark } & \multirow{3}{*}{ Water } & $1: 20$ & 9.70 & $226.60^{\mathrm{d}}$ & \\
\hline & & & $1: 10$ & 8.85 & $260.60^{\mathrm{d}}$ & (Polit1 et al., \\
\hline & & & $1: 5$ & 8.53 & $120.80^{\mathrm{d}}$ & \\
\hline & & Water & & 24.84 & $655.60^{\mathrm{c}}$ & \\
\hline & & Water $+1 \% \mathrm{Na}_{2} \mathrm{CO}_{3}$ & & 30.94 & $857.20^{\mathrm{c}}$ & \\
\hline Pinus ocarpa & Bark & Water $+5 \% \mathrm{Na}_{2} \mathrm{CO}_{3}$ & $1: 15,2 \mathrm{~h}$ & 35.74 & $890.70^{\mathrm{c}}$ & (Vieira et al., \\
\hline & & Water $+1 \% \mathrm{NaHSO}_{3}$ & & 19.86 & $846.40^{\mathrm{c}}$ & \\
\hline & & Water $+5 \% \mathrm{NaHSO}_{3}$ & & 26.70 & $722.80^{\mathrm{c}}$ & \\
\hline & & Water & $1: 5,6 h$ & 14.02 & $884.49^{\mathrm{c}}$ & (Antwi-Boasiako \\
\hline 1.leirapiera & 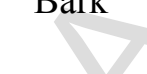 & Water $+1 \% \mathrm{NaOH}$ & b.p. & 75.29 & $374.60^{\mathrm{c}}$ & 2012) \\
\hline Galla & Whole & $\begin{array}{c}\text { 1-butyl-3- } \\
\text { methylimidazole } \\
\text { bromide } \\
{[\mathrm{C} 4 \mathrm{mim}] \mathrm{Br} 0.5 \mathrm{M}}\end{array}$ & $\begin{array}{l}\text { 1:15, 1min } \\
\text { UMAEd: } \\
\text { Microwave }\end{array}$ & & $380.00^{\mathrm{d}}$ & \\
\hline chinensis & plant & $\begin{array}{c}\text { 1-butyl-3- } \\
\text { methylimidazole } \\
\text { bromide } \\
{[\mathrm{C} 4 \mathrm{mim}] \mathrm{Br} 1.5 \mathrm{M}}\end{array}$ & $\begin{array}{l}400 \mathrm{~W} \\
\text { Ultrasound } \\
50 \mathrm{~W}\end{array}$ & --- & $555.00^{\mathrm{d}}$ & (Lu et al., 2012) \\
\hline
\end{tabular}




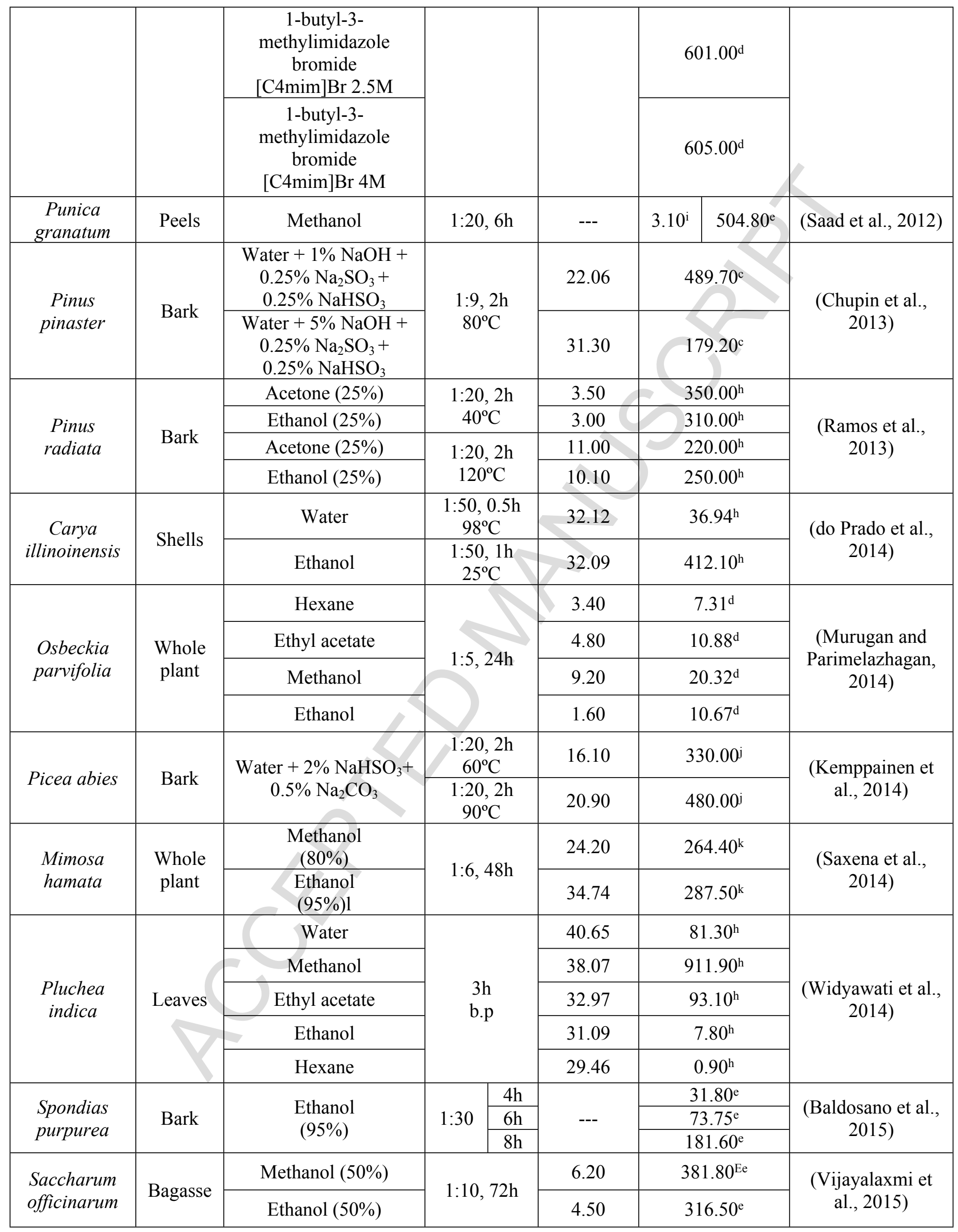




\begin{tabular}{|c|c|c|c|c|c|c|}
\hline \multirow{5}{*}{$\begin{array}{l}\text { Castanea } \\
\text { sativa }\end{array}$} & \multirow{5}{*}{ Peels } & Water & \multirow{5}{*}{$\begin{array}{l}1: 4,4 \mathrm{~h} \\
85^{\circ} \mathrm{C}\end{array}$} & 7.03 & $234.80^{\mathrm{c}}$ & \multirow{5}{*}{$\begin{array}{l}\text { (Aires et al., } \\
\text { 2016) }\end{array}$} \\
\hline & & Water $+1 \% \mathrm{Na}_{2} \mathrm{SO}_{3}$ & & 7.74 & $794.90^{\mathrm{c}}$ & \\
\hline & & Water $+4 \% \mathrm{Na}_{2} \mathrm{SO}_{3}$ & & 8.67 & $373.80^{\mathrm{c}}$ & \\
\hline & & Water $+1 \% \mathrm{NaOH}$ & & 11.63 & $728.70^{c}$ & \\
\hline & & Water $+4 \% \mathrm{NaOH}$ & & 66.59 & $415.00^{c}$ & \\
\hline \multirow{3}{*}{$\begin{array}{l}\text { Eucaliptus } \\
\text { globulus }\end{array}$} & \multirow{3}{*}{ Leaves } & $\begin{array}{c}\text { 1-butyl-3- } \\
\text { methylimidazole } \\
\text { bromide } \\
{[\mathrm{C} 4 \mathrm{mim}] \mathrm{Br} 0.6 \mathrm{M}}\end{array}$ & \multirow{3}{*}{$\begin{array}{c}1: 30,0.33 \mathrm{~h} \\
\mathrm{MAE}^{\mathrm{e}} \\
385 \mathrm{~W}\end{array}$} & \multirow{3}{*}{---} & $3.40^{\mathrm{f}^{*}}$ & \multirow{3}{*}{$\begin{array}{l}\text { (C. Liu et al., } \\
\text { 2016) }\end{array}$} \\
\hline & & $\begin{array}{c}\text { 1-butyl-3- } \\
\text { methylimidazole } \\
\text { bromide } \\
{[\mathrm{C} 4 \mathrm{mim}] \mathrm{Br} 1 \mathrm{M}}\end{array}$ & & & & \\
\hline & & $\begin{array}{c}\text { 1-butyl-3- } \\
\text { methylimidazole } \\
\text { bromide } \\
\text { [C4mim]Br 1.2M }\end{array}$ & & & 0 & \\
\hline \multirow{2}{*}{$\begin{array}{l}\text { Phyllantus } \\
\text { niruri } \\
\text { (Patiala } \\
\text { region) } \\
\end{array}$} & \multirow{2}{*}{$\begin{array}{l}\text { Whole } \\
\text { plant }\end{array}$} & Ethanol & \multirow{2}{*}{$1: 2,24 \mathrm{~h}$} & & $2.50^{\mathrm{i}}$ & \multirow{2}{*}{$\begin{array}{c}\text { (Kaur and Kaur, } \\
\text { 2016) }\end{array}$} \\
\hline & & Methanol & & & $16.00^{\mathrm{i}}$ & \\
\hline \multirow{4}{*}{ Vitis vinifera } & \multirow{4}{*}{ Skins } & $\begin{array}{c}\text { 1-butyl-3- } \\
\text { methylimidazolium } \\
\text { bromide } \\
{[\mathrm{C} 4 \mathrm{mim}] \mathrm{Br} 0.5 \mathrm{M}}\end{array}$ & & -- & $60.10^{j}$ & \multirow{4}{*}{$\begin{array}{c}\text { (Ćurko et al., } \\
\text { 2017) }\end{array}$} \\
\hline & & $\begin{array}{c}\text { 1-pentyl-3- } \\
\text { methylimidazolium } \\
\text { bromide } \\
{[\mathrm{C} 5 \mathrm{mim}] \mathrm{Br} 0.5 \mathrm{M}}\end{array}$ & $1: 10,4 \mathrm{~h}$ & & $41.30^{j}$ & \\
\hline & & $\begin{array}{c}\text { 1-heptyl-3- } \\
\text { methylimidazolium } \\
\text { bromide } \\
{[\mathrm{C} 7 \mathrm{mim}] \mathrm{Br} 0.5 \mathrm{M}}\end{array}$ & & & $38.60^{j}$ & \\
\hline & & $\begin{array}{c}\text { 1-decyl-3- } \\
\text { methylimidazolium } \\
\text { bromide } \\
{[\mathrm{C} 10 \mathrm{mim}] \mathrm{Br} 0.5 \mathrm{M}}\end{array}$ & & & $6.60^{\mathrm{j}}$ & \\
\hline
\end{tabular}

*Results expressed in mg of tannins per gram of dry matter.

aExtraction yield expressed in grams of extracts per grams of material.

${ }^{b} \mathrm{DE}=$ dry extract.

'Tannin content in extracts expressed in mg of reactive tannins/g dry extract (Stiasny number).

dTannin content in extracts expressed in gallic acid equivalents (GAE).

eTannin content in extracts expressed in tannic acid equivalents (TAE).

fHydrolysable tannin content in the extracts (HTC).

$\mathrm{g} b . \mathrm{p}=$ boiling point.

${ }^{\mathrm{h}}$ Content of extracts expressed in catechin equivalents (CE).

iTannin content in extracts expressed in cyaniding equivalents (CYE).

jCondensed tannin content in the extracts (CTC).

${ }^{\mathrm{k}}$ Tannin content in extracts expressed in quercetin equivalents $(\mathrm{QE})$. 
Table 4. Results related to the extraction of tannins via fluid at supercritical conditions

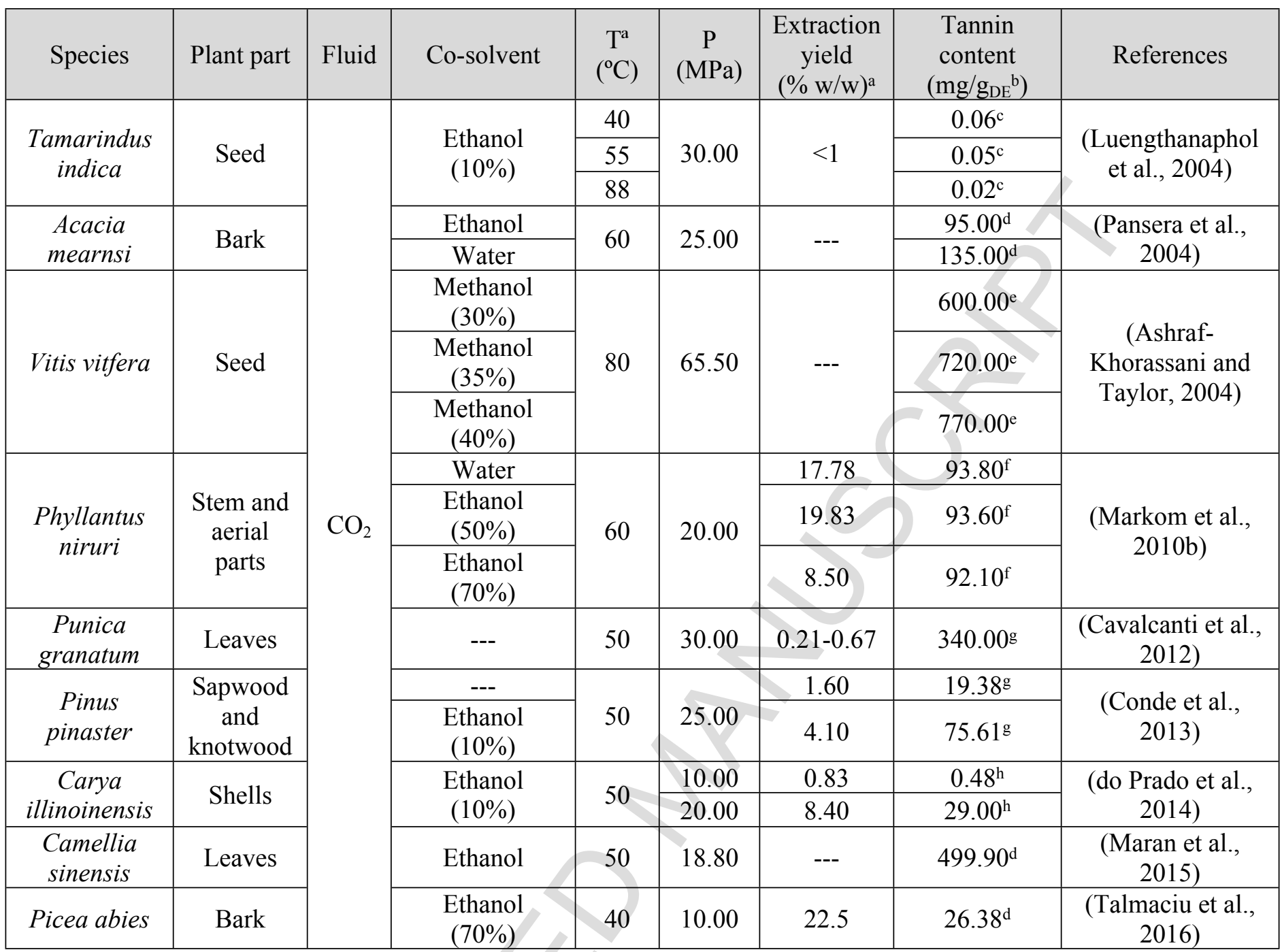

aExtraction yield expressed in grams of extracts per grams of material.

${ }^{b} \mathrm{DE}=$ dry extract.

${ }^{\mathrm{c}}$ Amount of epicatechin recovered in the extracts.

${ }^{\mathrm{d}}$ Tannin content in extracts expressed in tannic acid equivalents (TAE).

eAmount of catechin recovered in the extracts.

${ }^{\mathrm{f}}$ Total ellagitannin content in the extracts.

gTannin content in extracts expressed in gallic acid equivalents (GAE).

${ }^{\mathrm{h}}$ Tannin content in extracts expressed in catechin equivalents $(\mathrm{CE})$. 
Table 5. Results related to the extraction of tannins using water at high pressures and temperatures

\begin{tabular}{|c|c|c|c|c|c|c|c|}
\hline Species & Plant part & $\begin{array}{l}\text { Time } \\
(\min )\end{array}$ & $\begin{array}{c}\mathrm{T}^{\mathrm{a}} \\
\left({ }^{\circ} \mathrm{C}\right)\end{array}$ & $\begin{array}{c}\mathrm{P} \\
(\mathrm{MPa})\end{array}$ & $\begin{array}{c}\text { Extraction } \\
\text { yield } \\
(\% \mathrm{w} / \mathrm{w})^{\mathrm{a}} \\
\end{array}$ & $\begin{array}{l}\text { Tannin content } \\
\left(\mathrm{mg} / \mathrm{g}_{\mathrm{DE}}{ }^{\mathrm{b}}\right)\end{array}$ & References \\
\hline \multirow{3}{*}{ Vitis vinifera } & \multirow{3}{*}{ Seeds } & \multirow{3}{*}{30} & 50 & \multirow{3}{*}{10.34} & 4.20 & $615.47^{\mathrm{c}}$ & \multirow{3}{*}{$\begin{array}{l}\text { (García-Marino } \\
\text { et al., 2006) }\end{array}$} \\
\hline & & & 100 & & 12.40 & $405.67^{\mathrm{c}}$ & \\
\hline & & & 150 & & 37.70 & $505.44^{\mathrm{c}}$ & \\
\hline \multirow{3}{*}{$\begin{array}{l}\text { Terminalia } \\
\text { chebula }\end{array}$} & \multirow{3}{*}{ Fruits } & \multirow{3}{*}{37.50} & 120 & \multirow{3}{*}{4} & \multirow{3}{*}{--- } & $15.57^{\mathrm{d} *}$ & \multirow{3}{*}{$\begin{array}{c}\text { (Rangsriwong et } \\
\text { al., 2009) }\end{array}$} \\
\hline & & & 180 & & & $21.43^{\mathrm{d} *}$ & \\
\hline & & & 220 & & & $3.95^{\mathrm{d} *}$ & \\
\hline $\begin{array}{l}\text { Punica } \\
\text { granatum }\end{array}$ & Peels & 5 & 40 & 10.34 & 43.30 & \begin{tabular}{l|l}
$21.94^{\mathrm{c}}$ & $610.39^{\mathrm{e}}$
\end{tabular} & $\begin{array}{c}\text { (Çam and Hiş1l, } \\
\text { 2010) }\end{array}$ \\
\hline \multirow{4}{*}{$\begin{array}{l}\text { Phyllantus } \\
\text { niruri }\end{array}$} & \multirow{4}{*}{$\begin{array}{l}\text { Stem and } \\
\text { aerial parts }\end{array}$} & \multirow{4}{*}{60} & \multirow{4}{*}{100} & 5 & 21.50 & $100.46^{\mathrm{d}}$ & \multirow{4}{*}{$\begin{array}{c}\text { (Markom et al., } \\
\text { 2010a) }\end{array}$} \\
\hline & & & & 10 & 23.21 & $102.11^{\mathrm{d}}$ & \\
\hline & & & & 15 & 24.50 & $95.92^{\mathrm{d}}$ & \\
\hline & & & & 25 & 23.35 & $90.36^{\mathrm{d}}$ & \\
\hline $\begin{array}{c}\text { Rosmarinus } \\
\text { officinalis }\end{array}$ & \multirow{3}{*}{ Leaves } & \multirow{3}{*}{20} & \multirow{3}{*}{200} & \multirow{3}{*}{10.34} & 15.00 & $2.84^{\mathrm{f}}$ & \multirow{3}{*}{$\begin{array}{l}\text { (Plaza et al., } \\
\text { 2010) }\end{array}$} \\
\hline $\begin{array}{l}\text { Thymus } \\
\text { vulgaris }\end{array}$ & & & & & 14.80 & $188.48^{\mathrm{f}}$ & \\
\hline $\begin{array}{l}\text { Verbena } \\
\text { officinalis }\end{array}$ & & & & & 8.00 & $81.14^{\mathrm{f}}$ & \\
\hline \multirow{3}{*}{ Vitis vinifera } & \multirow{3}{*}{ Pomace } & \multirow{3}{*}{30} & \multirow{3}{*}{120} & 8 & & $12.29^{\mathrm{c}^{*}}$ & \multirow{3}{*}{$\begin{array}{c}\text { (Aliakbariana et } \\
\text { al., 2012) }\end{array}$} \\
\hline & & & & 11.50 & -- & $14.35^{\mathrm{c}^{*}}$ & \\
\hline & & & & 15 & & $11.52^{\mathrm{c}^{*}}$ & \\
\hline \multirow{2}{*}{ Vitis vinifera } & \multirow{2}{*}{ Pomace } & \multirow[b]{2}{*}{5} & 100 & & & $52.90^{\mathrm{c}}$ & (Vergara- \\
\hline & & & 200 & 10.34 & --- & $18.30^{c}$ & $\begin{array}{l}\text { Salinas et al., } \\
\text { 2013) }\end{array}$ \\
\hline $\begin{array}{c}\text { Larix } \\
\text { europaea }\end{array}$ & Barks & 30 & 100 & 2 & 10.50 & $381.90^{\mathrm{e}}$ & $\begin{array}{c}\text { (Ravber et al., } \\
\text { 2015) }\end{array}$ \\
\hline & & & 107.60 & & & $0.54^{\mathrm{f} *}$ & \\
\hline $\begin{array}{l}\text { Phyllantus } \\
\text { amarus }\end{array}$ & Aerial parts & 15 & 150.00 & 11 & --- & $3.15^{\mathrm{f} *}$ & $\begin{array}{c}\text { (Sousa et al., } \\
2016)\end{array}$ \\
\hline & & & 192.40 & & & $4.14^{\mathrm{f} *}$ & \\
\hline $\begin{array}{c}\text { Viola } \times \\
\text { wittrockiana }\end{array}$ & Flowers & 15 & --- & 250 & --- & $93.86^{\mathrm{e} *}$ & $\begin{array}{l}\text { (Fernandes et } \\
\text { al., 2017) }\end{array}$ \\
\hline & Industry & & & 0.1 & 5.32 & $0.46^{c^{*}}$ & \\
\hline Ficus carica & fermented & 30 & --- & 300 & 6.61 & $0.53^{c^{*}}$ & al., 2017) \\
\hline & byproducts & & & 600 & 7.13 & $0.49^{c^{*}}$ & \\
\hline & +3 & & 110 & & 59.10 & $41.46^{\mathrm{g}}$ & \\
\hline Pistacia vera & Hulls & 50 & $\begin{array}{l}150 \\
190\end{array}$ & 6.9 & $\begin{array}{l}70.90 \\
65.30\end{array}$ & $\begin{array}{l}45.84^{\mathrm{g}} \\
31.24^{\mathrm{g}}\end{array}$ & 2018) \\
\hline
\end{tabular}

*Results expressed in mg of tannins per gram of dry matter.

aExtraction yield expressed in grams of extracts per grams of material.

${ }^{b} \mathrm{DE}=$ dry extract.

'Tannin content in extracts expressed in catechin equivalents (CE).

${ }^{\mathrm{d}}$ Hydrolysable tannin content in extracts (gallotannins+ellagitannins+coraligin).

eTannin content in extracts expressed in tannic acid equivalents (TAE)

fTannin content in extracts expressed in gallic acid equivalents (GAE)

gGallotannin content in extracts obtained by HPLC 
Table 6. Results devoted to the extraction of tannins assisted by microwave

\begin{tabular}{|c|c|c|c|c|c|c|c|c|c|c|}
\hline \multirow[b]{2}{*}{ Species } & \multirow{2}{*}{$\begin{array}{c}\text { Plant } \\
\text { part }\end{array}$} & \multicolumn{5}{|c|}{ Extraction conditions } & \multirow{2}{*}{$\begin{array}{l}\text { Extraction } \\
\text { Yield } \\
(\% \mathrm{w} / \mathrm{w})^{\mathrm{a}}\end{array}$} & \multirow{2}{*}{\multicolumn{2}{|c|}{$\begin{array}{l}\text { Tannin content } \\
\left(\mathrm{mg} / \mathrm{g}_{D^{2}}{ }^{\mathrm{a}}\right)\end{array}$}} & \multirow[b]{2}{*}{ References } \\
\hline & & Solvent & $\begin{array}{c}\mathrm{S} / \mathrm{L} \\
(\mathrm{g} / \mathrm{mL})\end{array}$ & $\begin{array}{c}\mathrm{T} \\
\left({ }^{\circ} \mathrm{C}\right)\end{array}$ & $\begin{array}{l}\text { Time } \\
\text { (min) }\end{array}$ & $\begin{array}{l}\text { Power } \\
\text { (W) }\end{array}$ & & & & \\
\hline Vitis vinifera & Seed & $\begin{array}{c}\text { Methanol } \\
(90 \%)\end{array}$ & $1: 15$ & 73 & 3.33 & 30 & 15.12 & 429 & $0^{\mathrm{c} *}$ & $\begin{array}{l}\text { (Hong et } \\
\text { al., 2001) }\end{array}$ \\
\hline \multirow[b]{2}{*}{$\begin{array}{c}\text { Radix } \\
\text { puerariae }\end{array}$} & \multirow[b]{2}{*}{$\begin{array}{l}\text { Whole } \\
\text { plant }\end{array}$} & \multirow{2}{*}{$\begin{array}{c}\text { Ethanol } \\
(70 \%)\end{array}$} & $1: 20$ & \multirow[b]{2}{*}{---} & \multirow[b]{2}{*}{6.50} & \multirow[b]{2}{*}{255} & \multirow[b]{2}{*}{--- } & \multirow{2}{*}{\multicolumn{2}{|c|}{$\begin{array}{l}5.75^{\mathrm{d}} \\
8.00^{\mathrm{d}}\end{array}$}} & \multirow[b]{2}{*}{$\begin{array}{l}\text { (Wang et } \\
\text { al., 2010) }\end{array}$} \\
\hline & & & $\begin{array}{l}1: 30 \\
1: 40\end{array}$ & & & & & & & \\
\hline $\begin{array}{c}\text { Cinnamomum } \\
\text { zeylanicum }\end{array}$ & Leaves & \multirow{4}{*}{$\begin{array}{l}\text { Ethanol } \\
(50 \%)\end{array}$} & \multirow{4}{*}{$1: 20$} & \multirow{4}{*}{50} & \multirow{4}{*}{18.00} & \multirow{4}{*}{200} & & 16 & & \multirow{4}{*}{$\begin{array}{l}\text { (Gallo et } \\
\text { al., 2010) }\end{array}$} \\
\hline Crocus sativus & Powder & & & & & & & 29 & & \\
\hline $\begin{array}{c}\text { Coriandrum } \\
\text { sativum }\end{array}$ & \multirow{2}{*}{ Seeds } & & & & & & & & & \\
\hline $\begin{array}{l}\text { Cuminum } \\
\text { cyminum }\end{array}$ & & & & & & & & 11 & & \\
\hline \multirow{2}{*}{$\begin{array}{l}\text { Agrimonia } \\
\text { pilosa }\end{array}$} & \multirow{2}{*}{$\begin{array}{l}\text { Stems } \\
\text { and } \\
\text { roots }\end{array}$} & \multirow[b]{2}{*}{ Acetone } & \multirow[b]{2}{*}{$1: 35$} & \multirow[b]{2}{*}{30} & \multirow[b]{2}{*}{15.00} & 300 & & 99 & & \multirow{2}{*}{$\begin{array}{c}\text { (Jin et al., } \\
\text { 2010) }\end{array}$} \\
\hline & & & & & & 500 & & 128 & & \\
\hline \multirow{3}{*}{$\begin{array}{l}\text { Buddleia } \\
\text { officinalis }\end{array}$} & \multirow{3}{*}{$\begin{array}{l}\text { Whole } \\
\text { platn }\end{array}$} & $\begin{array}{l}\text { Ethanol } \\
(75 \%)\end{array}$ & & & & & & 55 & & \\
\hline & & $\begin{array}{l}\text { Ethanol } \\
(95 \%)\end{array}$ & $1: 10$ & 78 & 10 & 900 & --- & 62. & & $\begin{array}{l}\text { (Pan et al., } \\
\text { 2010) }\end{array}$ \\
\hline & & $\begin{array}{l}\text { Ethanol } \\
\text { pure }\end{array}$ & & & & & & 58. & & \\
\hline Vitis vinifera & Seeds & $\begin{array}{l}\text { Ethanol } \\
(70 \%)\end{array}$ & $1: 40$ & 60 & 2.00 & 125 & 16.40 & 528 & & $\begin{array}{l}\text { (Li et al., } \\
\text { 2011) }\end{array}$ \\
\hline Pinus radiata & Bark & $\begin{array}{l}\text { Acetone } \\
(70 \%)\end{array}$ & $1: 10$ & 25 & 3.00 & 900 & 10.40 & 523 & & $\begin{array}{l}\text { (Aspé and } \\
\text { Fernández, } \\
\text { 2011) }\end{array}$ \\
\hline & & & & 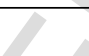 & & 180 & & & & (Švarc- \\
\hline officinalis & Leaves & $(70 \%)$ & $1:$ & 70 & 5.00 & 320 & --- & & & Gajić et al., \\
\hline & & & & & & 800 & & & & \\
\hline Pinus pinaster & Bark & $\begin{array}{l}\text { Acetone } \\
(80 \%)\end{array}$ & $1: 20$ & --- & 3.00 & 100 & 13.60 & 48. & & $\begin{array}{l}\text { (Chupin et } \\
\text { al., 2015) }\end{array}$ \\
\hline $\begin{array}{c}\text { Myrtus } \\
\text { communis }\end{array}$ & Leaves & $\begin{array}{l}\text { Ethanol } \\
(42 \%)\end{array}$ & $1: 32$ & --- & 1.04 & 500 & --- & 32 & & $\begin{array}{l}\text { (Dahmoune } \\
\text { et al., 2015) }\end{array}$ \\
\hline Acacia & Bark & Water & $1 \cdot 20$ & --- & 500 & 150 & --- & $47.64^{\mathrm{h}}$ & $0.09^{\mathrm{c}}$ & (Naima et \\
\hline mollissima & DálK & Ethanol & & -- & & & -- & $30.29^{\mathrm{h}}$ & $0.03^{\mathrm{c}}$ & al., 2015) \\
\hline $\begin{array}{l}\text { Eucalyptus } \\
\text { globulus }\end{array}$ & Leaves & $\begin{array}{c}\text { Ethanol } \\
(45 \%)\end{array}$ & $1: 30$ & --- & 4.50 & 340 & --- & 4. & & $\begin{array}{l}\text { (Huma et } \\
\text { al., 2018) }\end{array}$ \\
\hline
\end{tabular}

*Results expressed in mg of tannins per gram of dry extract.

aExtraction yield expressed in grams of extracts per grams of material.

${ }^{\mathrm{b}} \mathrm{DM}=$ dry matter.

${ }^{\mathrm{c}}$ Tannin content in extracts expressed in tannic acid equivalents (TAE).

dRutin content in the extracts (RC).

'Tannin content in extracts expressed in gallic acid equivalents (GAE).

${ }^{\mathrm{f}}$ Tannin content in extracts expressed in catechin equivalents (CE).

${ }^{g}$ CAmount of condensed tannins precipitated from extracts (CTP).

${ }^{\mathrm{h}}$ Tannin content in extracts expressed in cyaniding equivalents $(\mathrm{CyE})$. 
Table 7. Results related to the extraction of tannins assisted by ultrasound

\begin{tabular}{|c|c|c|c|c|c|c|c|c|c|}
\hline \multirow[b]{2}{*}{ Species } & \multirow{2}{*}{$\begin{array}{l}\text { Plant } \\
\text { part }\end{array}$} & \multicolumn{5}{|c|}{ Extraction conditions } & \multirow{2}{*}{$\begin{array}{c}\text { Extraction } \\
\text { Yield } \\
(\% \mathrm{w} / \mathrm{w})^{\mathrm{a}}\end{array}$} & \multirow{2}{*}{$\begin{array}{c}\text { Tannin } \\
\text { content } \\
\left(\mathrm{mg} / \mathrm{g}_{\mathrm{DM}} \mathrm{b}\right)\end{array}$} & \multirow[b]{2}{*}{ References } \\
\hline & & Solvent & $\begin{array}{c}\mathrm{S} / \mathrm{L} \\
(\mathrm{g} / \mathrm{mL})\end{array}$ & $\begin{array}{c}\mathrm{T} \\
\left({ }^{\circ} \mathrm{C}\right)\end{array}$ & $\begin{array}{l}\text { Time } \\
(\min )\end{array}$ & $\begin{array}{l}\text { Power } \\
(\mathrm{W})\end{array}$ & & & \\
\hline \multirow{3}{*}{ Leucaena spp } & \multirow{3}{*}{ Leaves } & \multirow{3}{*}{$\begin{array}{c}\text { Acetone } \\
70 \%\end{array}$} & \multirow{3}{*}{$1: 50$} & \multirow{3}{*}{25} & 15 & \multirow{3}{*}{---} & \multirow{3}{*}{---} & $86.10^{\mathrm{c}}$ & \multirow{3}{*}{$\begin{array}{c}\text { (Dalzell and } \\
\text { Kerven, 1998) }\end{array}$} \\
\hline & & & & & 20 & & & $89.80^{\mathrm{c}}$ & \\
\hline & & & & & 30 & & & $88.10^{\mathrm{c}}$ & \\
\hline $\begin{array}{c}\text { Betula } \\
\text { alleghaniensis }\end{array}$ & Foliage & $\begin{array}{l}\text { Ethanol } \\
(95 \%)\end{array}$ & --- & 20 & 30 & 750 & 14.80 & $43.00^{\mathrm{d} *}$ & $\begin{array}{c}\text { (Diouf et al., } \\
\text { 2009) }\end{array}$ \\
\hline \multirow{3}{*}{$\begin{array}{l}\text { Averrhoa } \\
\text { carambola }\end{array}$} & \multirow{3}{*}{ Fruit } & \multirow{3}{*}{ Methanol } & \multirow{3}{*}{$1: 10$} & \multirow{3}{*}{25} & 15 & \multirow{3}{*}{135} & 4.80 & $11.70^{\mathrm{e} *}$ & \multirow{3}{*}{$\begin{array}{l}\text { (Annegowda } \\
\text { et al., 2012) }\end{array}$} \\
\hline & & & & & 30 & & 4.70 & $11.20^{\mathrm{e} *}$ & \\
\hline & & & & & 45 & & 4.30 & $10.90^{\mathrm{e} *}$ & \\
\hline Vitis vinifera & $\begin{array}{l}\text { Full } \\
\text { berry }\end{array}$ & $\begin{array}{c}\text { Ethanol } \\
(50 \%)\end{array}$ & $1: 10$ & 10 & 6 & 200 & & $6.00^{\mathrm{f}}$ & $\begin{array}{c}\text { (Carrera et al., } \\
\text { 2012) }\end{array}$ \\
\hline Vitis vinifera & Seeds & Methanol & $1: 10$ & 30 & 15 & 150 & & $61.80^{\mathrm{e}}$ & $\begin{array}{l}\text { (Da Porto et } \\
\text { al., 2013) }\end{array}$ \\
\hline \multirow{3}{*}{ Areca catechu } & \multirow{3}{*}{ Nuts } & \multirow{3}{*}{$\begin{array}{l}\text { Acetone } \\
(80 \%)\end{array}$} & \multirow{3}{*}{$1: 10$} & \multirow{3}{*}{---} & \multirow{3}{*}{37.50} & 10 & & $44.53^{\mathrm{e}}$ & \multirow{3}{*}{$\begin{array}{c}\text { (Chavan and } \\
\text { Singhal, 2013) }\end{array}$} \\
\hline & & & & & & 50 & & $101.60^{\mathrm{e}}$ & \\
\hline & & & & & & 90 & & $37.02^{\mathrm{e}}$ & \\
\hline \multirow{3}{*}{$\begin{array}{l}\text { Withania } \\
\text { somnifera }\end{array}$} & \multirow{3}{*}{ Roots } & Ethanol & & & & 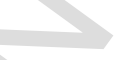 & 3.17 & $29.15^{\mathrm{g} *}$ & \\
\hline & & $\begin{array}{l}\text { Ethanol } \\
(10 \%)\end{array}$ & $1: 10$ & 25 & 20 & 480 & 9.08 & $22.12^{\mathrm{g} *}$ & $\begin{array}{l}\text { (Dhanani et } \\
\text { al., 2013) }\end{array}$ \\
\hline & & Water & & & & & 10.27 & $18.18^{g *}$ & \\
\hline Quercus & & $\begin{array}{c}\text { Methanol } \\
(50 \%)\end{array}$ & & & 45 & & 21.10 & $104.50^{\mathrm{e} *}$ & (Tabaraki et \\
\hline brantii & Leaves & $\begin{array}{c}\text { Methanol } \\
(90 \%)\end{array}$ & $1: 20$ & & 45 & 140 & 25.30 & $127.00^{\mathrm{e} *}$ & al., 2013) \\
\hline $\begin{array}{l}\text { Pistacia } \\
\text { lentiscus }\end{array}$ & Leaves & $\begin{array}{c}\text { Ethanol } \\
(40 \%)\end{array}$ & & & 15 & 130 & --- & $35.94^{\mathrm{f}}$ & $\begin{array}{c}\text { (Dahmoune et } \\
\text { al., 2014) }\end{array}$ \\
\hline Rubus & & & & 25 & 15 & & 5.30 & $5.09^{\mathrm{h} *}$ & (Ivanovic et \\
\hline fruticosus & Fruits & thanol & & 25 & 30 & 60 & 5.90 & $25.42^{\mathrm{h} *}$ & al., 2014) \\
\hline $\begin{array}{l}\text { Phyllantus } \\
\text { amarus }\end{array}$ & $\begin{array}{l}\text { Aerial } \\
\text { parts }\end{array}$ & \begin{tabular}{|c|} 
Deionized \\
water
\end{tabular} & & 25 & 7 & 301 & --- & $27.23^{\mathrm{g}}$ & $\begin{array}{l}\text { (Sousa et al., } \\
\text { 2016) }\end{array}$ \\
\hline & Flowers, & & & & & 90 & 8.75 & $31.44^{\mathrm{d}}$ & \\
\hline $\begin{array}{c}\text { Cannabis } \\
\text { sativa }\end{array}$ & $\begin{array}{l}\text { leaves } \\
\text { and seed }\end{array}$ & $\begin{array}{c}\text { Methanol } \\
(80 \%)\end{array}$ & $1: 25$ & --- & 15 & 120 & 11.29 & $40.39^{d}$ & $\begin{array}{l}\text { (Agarwal et } \\
\text { al. 2018) }\end{array}$ \\
\hline & husks & $(00 / 0)$ & & & & 150 & 9.68 & $39.19^{d}$ & \\
\hline Piper betle & Leaves & $\begin{array}{l}\text { Ethanol } \\
(78.74 \%)\end{array}$ & $1: 21.85$ & 51.60 & 30 & 400 & 13.71 & $21.5^{\mathrm{i}}$ & $\begin{array}{c}\text { (Ali et al., } \\
\text { 2018) }\end{array}$ \\
\hline $\begin{array}{l}\text { Vitis vinifera } \\
\text { (Tempranillo) }\end{array}$ & Pomace & $\begin{array}{c}\text { Ethanol } \\
(44 \%)\end{array}$ & $1: 5$ & 50 & 3 & 500 & --- & $86.67^{\mathrm{f}}$ & $\begin{array}{c}\text { (Poveda et al., } \\
\text { 2018) }\end{array}$ \\
\hline
\end{tabular}

* Results expressed in mg of tannins per gram of dry extract.

${ }^{a}$ Extraction yield expressed in grams of extracts per grams of material.

${ }^{b} \mathrm{DM}=$ dry matter.

'Tannin content in extracts expressed in L leucocephale proanthocyanidin equivales (LPAE).

${ }^{\mathrm{d}}$ Tannin content in extracts expressed in quercetin equivalents (QE).

eTannin content in extracts expressed in catechin equivalents 
fTotal content of condensed tannins in extracts (TCT).

gTannin content in extracts expressed in gallic acid equivalents (GAE).

${ }^{\mathrm{h}}$ Total tannin content in extracts (TTC).

${ }^{\mathrm{i} T}$ Tannin content in extracts expressed in rutin equivalents (RE). 
Table 8. Results devoted to the assessment and comparison of the different tannins extraction methods

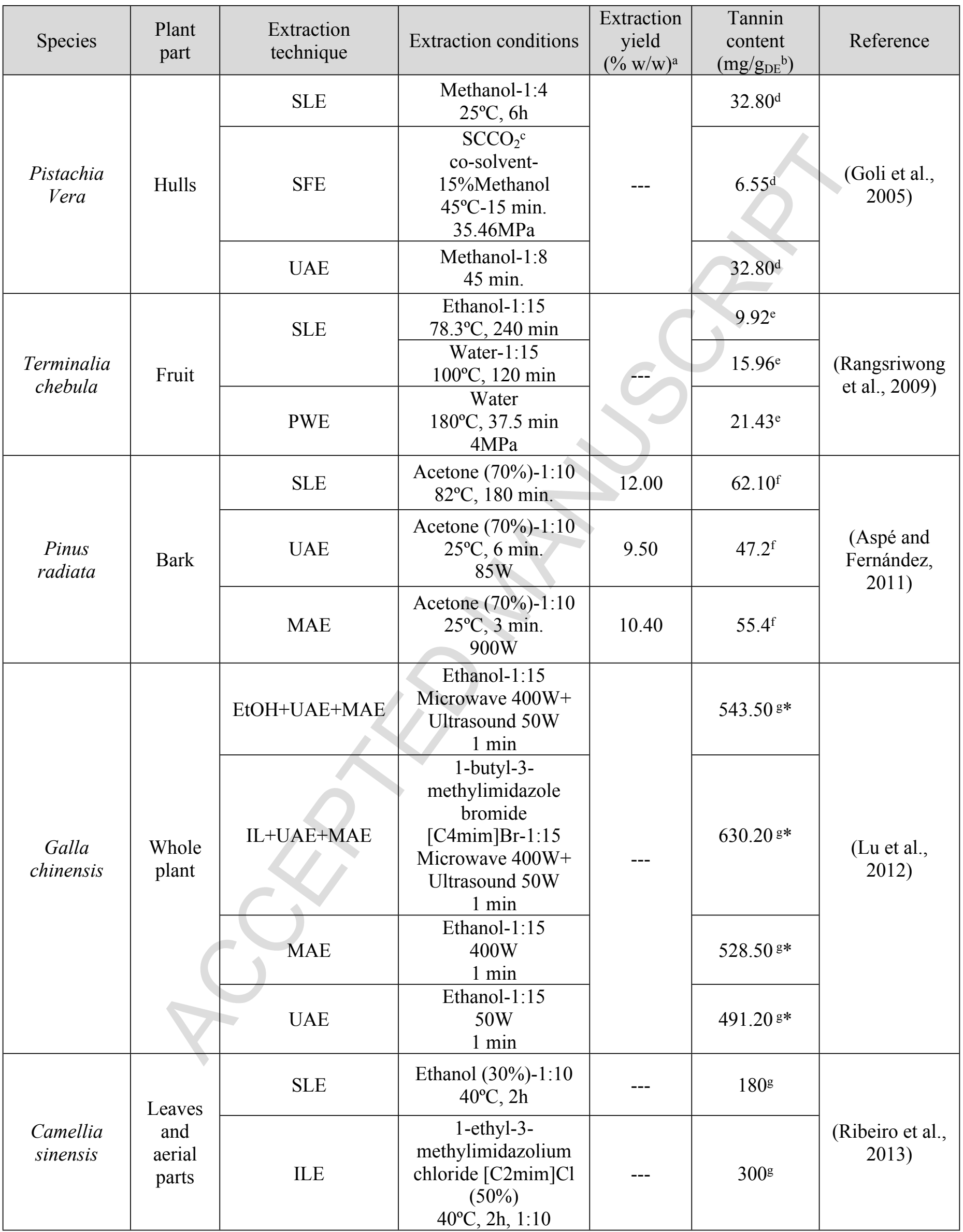




\begin{tabular}{|c|c|c|c|c|c|c|}
\hline \multirow{4}{*}{ Rubus sp. } & \multirow{4}{*}{ Bagasse } & SLE & $\begin{array}{c}\text { Ethanol-1:31.60 } \\
50^{\circ} \mathrm{C}, 6-8 \mathrm{~h}\end{array}$ & 14.58 & $4.25^{\mathrm{g} *}$ & \multirow{4}{*}{$\begin{array}{l}\text { (Reátegui et } \\
\text { al., 2014) }\end{array}$} \\
\hline & & SFE & $\begin{array}{c}\mathrm{SCCO}_{2}{ }^{\mathrm{c}} \\
\text { no cosolvent, } 15 \mathrm{MPa} \\
120 \mathrm{~min} .\end{array}$ & 6.84 & $4.07 \mathrm{~g} *$ & \\
\hline & & \multirow{2}{*}{$\mathrm{SFE}+\mathrm{UAE}$} & $\begin{array}{c}\mathrm{SCCO}_{2}{ }^{\mathrm{c}} \\
\text { no cosolvent, } 15 \\
\mathrm{MPa} \\
400 \mathrm{~W}, 57 \mathrm{~min} .\end{array}$ & 7.94 & $3.53^{\mathrm{g} *}$ & \\
\hline & & & $\begin{array}{c}\mathrm{SCCO}_{2}{ }^{\mathrm{c}} \\
\text { cosolvent- } \\
10 \% \text { Ethanol, } 15 \mathrm{MPa} \\
200 \mathrm{~W}, 57 \mathrm{~min} \\
\end{array}$ & 18.25 & $12.73^{\mathrm{g} *}$ & \\
\hline \multirow{2}{*}{$\begin{array}{l}\text { Solidago } \\
\text { canadensis }\end{array}$} & \multirow{2}{*}{ Bark } & SLE & $\begin{array}{c}\text { Ethanol }(50 \%)-1: 20 \\
25^{\circ} \mathrm{C}, 30 \mathrm{~min} .\end{array}$ & & $26.29^{h}$ & \multirow{2}{*}{$\begin{array}{l}\text { (Deng et al., } \\
\text { 2015) }\end{array}$} \\
\hline & & UAE & $\begin{array}{c}\text { Ethanol }(50 \%)-1: 20 \\
30 \mathrm{~min}\end{array}$ & & $30.15^{\mathrm{h}}$ & \\
\hline \multirow[b]{2}{*}{$\begin{array}{l}\text { Myrtus } \\
\text { comunis }\end{array}$} & \multirow[b]{2}{*}{ Leaves } & UAE & $\begin{array}{c}\text { Ethanol }(96 \%)-1: 5.4 \\
30 \mathrm{~min} . \\
320 \mathrm{~W}\end{array}$ & 10.81 & $324.34^{\mathrm{g} *}$ & \multirow{2}{*}{$\begin{array}{c}\text { (Pereira et al., } \\
2017,2016)\end{array}$} \\
\hline & & SFE & $\begin{array}{c}\mathrm{SCCO}_{2}{ }^{\mathrm{c}} \\
\text { co-solvent-Ethanol } \\
45^{\circ} \mathrm{C}, 700 \mathrm{~min} . \\
23 \mathrm{MPa} \\
\end{array}$ & 10.80 & $\begin{array}{l}47.28- \\
94.56^{\mathrm{g} *}\end{array}$ & \\
\hline \multirow{3}{*}{$\begin{array}{c}\text { Berberis } \\
\text { jaeschkeana }\end{array}$} & \multirow{3}{*}{ Fruits } & SLE & $\begin{array}{c}\text { Methanol 80\%-1:70 } \\
70^{\circ} \mathrm{C}-15 \mathrm{~min} .\end{array}$ & \multirow{3}{*}{---} & $21.41^{\mathrm{d}}$ & \multirow{3}{*}{$\begin{array}{c}\text { (Belwal et al., } \\
\text { 2017) }\end{array}$} \\
\hline & & UAE & $\begin{array}{c}\text { Methanol 80\%-1:70 } \\
70^{\circ} \mathrm{C}-15 \mathrm{~min} .\end{array}$ & & $32.41^{\mathrm{d}}$ & \\
\hline & & MAE & $\begin{array}{c}\text { Methanol 80\%-1:40 } \\
5 \text { min. } \\
670 \mathrm{~W} \\
\end{array}$ & & $24.04^{\mathrm{d}}$ & \\
\hline \multirow{2}{*}{$\begin{array}{l}\text { Myrtus } \\
\text { communis }\end{array}$} & \multirow[b]{2}{*}{ Leaves } & SLE & $\begin{array}{c}\text { Ethanol } 42 \%-1: 50 \\
120 \mathrm{~min} .\end{array}$ & \multirow[b]{2}{*}{---} & $36.01^{\mathrm{f}}$ & \multirow{2}{*}{$\begin{array}{l}\text { (Bouaoudia- } \\
\text { Madi et al., } \\
\text { 2017) }\end{array}$} \\
\hline & & MAE & $\begin{array}{c}\text { Ethanol } 42 \%-1: 30 \\
1 \mathrm{~min} \\
500 \mathrm{~W} \\
\end{array}$ & & $34.50^{\mathrm{f}}$ & \\
\hline \multirow{3}{*}{$\begin{array}{l}\text { Salacia } \\
\text { chinensis }\end{array}$} & \multirow{3}{*}{ Roots } & SLE & $\begin{array}{l}\text { Methanol-1:10 } \\
25^{\circ} \mathrm{C}, 360 \mathrm{~min} .\end{array}$ & & $43.37^{\mathrm{d}}$ & \multirow{3}{*}{$\begin{array}{l}\text { (Ghadage et } \\
\text { al., 2017) }\end{array}$} \\
\hline & & UAE & $\begin{array}{l}\text { Methanol-1:10 } \\
25^{\circ} \mathrm{C}, 10 \mathrm{~min} .\end{array}$ & --- & $41.29^{\mathrm{d}}$ & \\
\hline & & MAE & $\begin{array}{l}\text { Methanol-1:10 } \\
25^{\circ} \mathrm{C}, 5 \mathrm{~min} . \\
180 \mathrm{~W}\end{array}$ & & $43.54^{\mathrm{d}}$ & \\
\hline \multirow{2}{*}{ Erica carnea } & \multirow{2}{*}{$\begin{array}{l}\text { Aerial } \\
\text { parts }\end{array}$} & SLE & $\begin{array}{c}\text { Ethanol } 96 \%-1: 30 \\
22^{\circ} \mathrm{C}, 7 \text { days } \\
\text { (maceration) }\end{array}$ & 15.30 & $57.19^{\mathrm{g}}$ & \multirow{2}{*}{$\begin{array}{c}\text { (Veličković et } \\
\text { al., 2017) }\end{array}$} \\
\hline & & UAE & $\begin{array}{c}\text { Ethanol } 96 \%-1: 20 \\
30 \mathrm{~min} \\
216 \mathrm{~W}\end{array}$ & 18.33 & $60.65^{\mathrm{g}}$ & \\
\hline
\end{tabular}




\begin{tabular}{|c|c|c|c|c|c|c|}
\hline & & MAE & $\begin{array}{c}\text { Ethanol } 96 \%-1: 20 \\
30 \mathrm{~min} \\
600 \mathrm{~W} \\
\end{array}$ & 30.65 & $61.70^{\mathrm{g}}$ & \\
\hline & & PWE & $\begin{array}{c}\text { Water-1:20 } \\
140^{\circ} \mathrm{C}, 30 \text { min. } \\
4 \mathrm{MPa}\end{array}$ & 42.66 & $62.53^{\mathrm{g}}$ & \\
\hline \multirow{4}{*}{$\begin{array}{l}\text { Lavatera } \\
\text { thuringiaca }\end{array}$} & \multirow{4}{*}{$\begin{array}{l}\text { Whole } \\
\text { plant }\end{array}$} & SLE & $\begin{array}{c}\text { Ethanol } 96 \%-1: 30 \\
22^{\circ} \mathrm{C}, 8 \mathrm{~h}\end{array}$ & \multirow{4}{*}{--- } & $65.61^{\mathrm{g} *}$ & \multirow{4}{*}{$\begin{array}{l}\text { (Mašković et } \\
\text { al., 2018) }\end{array}$} \\
\hline & & UAE & $\begin{array}{c}\text { Ethanol } 96 \%-1: 20 \\
30 \mathrm{~min} \\
216 \mathrm{~W}\end{array}$ & & $71.78^{\mathrm{g} *}$ & \\
\hline & & MAE & $\begin{array}{c}\text { Ethanol } 96 \%-1: 20 \\
30 \mathrm{~min} \\
600 \mathrm{~W}\end{array}$ & & & \\
\hline & & PWE & $\begin{array}{c}\text { Water-1:20 } \\
140^{\circ} \mathrm{C}, 30 \mathrm{~min} . \\
4 \mathrm{MPa}\end{array}$ & & & \\
\hline
\end{tabular}

*Results expressed in mg of tannins per gram of dry matter.

aExtraction yield expressed in grams of extracts per grams of material.

${ }^{b} \mathrm{DE}=$ dry extract.

${ }^{\mathrm{c}} \mathrm{SCCO}_{2}=$ carbon dioxide at supercritical conditions.

${ }^{\mathrm{d}}$ Tannin content in extracts expressed in tannic acid equivalents (TAE).

eHydrolysable tannin content in extracts (HTC)

fTannin content in extracts expressed in catechin equivalents (CE).

gTannin content in extracts expressed in gallic acid equivalents (GAE).

hTotal tannin content in the extracts (TTC). 
